\title{
LECHOSŁAW JOCZ
}

Akademia im. Jakuba z Paradyża w Gorzowie Wielkopolskim

\section{MIEJSCE GWARY LUZIŃSKIEJ WŚRÓD GWAR KASZUBSKICH W ŚWIETLE FAKTÓW FONETYCZNYCH I FONOLOGICZNYCH}

\section{Wstęp}

Pierwszy raz odwiedziłem Luzino w marcu 2012 roku, bezpośrednio po intensywnych badaniach terenowych na obszarze gwar centralnokaszubskich okolic Kartuz i Sierakowic ${ }^{1}$. Wykonałem wówczas w Luzinie godzinne nagranie z jednym informatorem. Moje wrażenia z prac poprzedzających pobyt na obszarze gwary luzińskiej były wtedy bardzo świeże. Niemniej jednak nabrałem od razu pełnego przeświadczenia, że nie sposób pod względem fonetycznym i fonologicznym sprowadzić gwary luzińskiej do wspólnego mianownika z gwarami okolic Kartuz i Sierakowic. Nie zmieniły tego przekonania w najmniejszym stopniu późniejsze nagrania uzupełniające na obszarze centralnokaszubskim z sierpnia 2013 roku, w których rozszerzyłem obszar zasadniczych moich badań nieco na północ i południowy wschód ${ }^{2}$. Materiału luzińskiego w związku z tym do opisów systemu samogłoskowego, spółgłoskowego oraz akcentowego centralnej kaszubszczyzny nie włączyłem (Jocz 2013, Jocz 2014, Jocz 2015a) 3. Do gwary luzińskiej wróciłem na krótko w listopadzie 2014 roku, wykonując nagrania ankietowe z dwoma informatorami (po jednym z Luzina i Częstkowa). Odwiedziłem wtedy również peryferyjne gwary północnokaszubskie: żarnowiecką (Wierzchucino i Nadole) (Jocz 2015c) oraz dwie bylackie (Chłapowo, Jastarnia; materiały dotychczas nieopublikowane), co dało mi możliwość samodzielnego spojrzenia na gwarę luzińską z perspektywy współczesnej kaszubszczyzny północnej ${ }^{4}$ Do specjalnego zajęcia się zagadnieniem miejsca gwary luzińskiej wśród gwar kaszubskich

\footnotetext{
${ }^{1}$ Główne punkty terenowe to Sierakowice, Gowidlino, Mściszewice, Kożyczkowo, Cieszenie, Sznurki, Mezowo i Glińcz.

${ }^{2}$ Główne punkty terenowe to Bącz, Mirachowo, Brodnica Górna i Hopy.

${ }^{3}$ Publikacje te i ww. nagrania i powstały w ramach projektu Vergleichende Phonetik der obersorbischen und kaschubischen Sprache, finansowanego przez Niemiecką Wspólnotę Badawczą (DFG). Numer Projektu: JO 949/1-1.

${ }^{4}$ Nagrania te przeprowadziłem w ramach projektu Sound Comparisons, realizowanego w Instytucie Antropologii Ewolucyjnej im. Maksa Plancka w Lipsku, a następnie w Instytucie Historii Ludzkości im. Maksa Plancka w Jenie.
} 
- które zainteresowało mnie już w 2012 roku - skłoniły mnie bezpośrednio wnioski z badań nad wokalizmem luzińskim (Jocz 2016) ${ }^{5}$, które przeprowadziłem wiosną 2016 roku. Kierowany w pewnej mierze chęcią opracowania tego problemu wykonałem w maju 2016 roku kilka obszerniejszych nagrań ankietowych na obszarze gwary strzepskiej (materiały dotychczas nieopublikowane), sąsiadującej z gwarą luzińską od południa (abstrahuję tu od niewielkich, odrębnych obszarów gwarowych, częściowo oddzielających gwarę strzepską i luzińską). Pomocne w pewnym zakresie będzie dla mnie również nagranie $\mathrm{z}$ młodym informatorem, zamieszkałym w Czeczewie, ale reprezentującym gwarę Bojana, wykonane W sierpniu 2013 roku.

$\mathrm{Z}$ powodu charakteru zgromadzonego przeze mnie materiału oraz (prze)prowadzonych badań rozpatruję zagadnienie wyłącznie z punktu widzenia fonetycznego i fonologicznego. Podkreślić tu należy, iż w ciągu ostatnich kilkudziesięciu lat gwary kaszubskie wykazywały wybitną niekiedy dynamikę rozwoju systemu dźwiękowego, uwarunkowaną w przeważającej mierze czynnikami wewnętrznymi (bardzo często niedawne zmiany głosowe oddalają gwary kaszubskie od ogólnej polszczyzny). Dotyczy to również (a może nawet zwłaszcza) zachodnich gwar centralnokaszubskich, najbliższych geograficznie gwarze luzińskiej. Opierając się na opisach najnowszych zmian - zarejestrowanych w dotychczasowej literaturze w bardzo ograniczonym stopniu lub wręcz zupełnie nieznanych czy pominiętych przed moimi badaniami - będę mógł ustalić procesy integracyjne i dezintegracyjne najświeższej daty i ewentualne aktualne związki pomiędzy poszczególnymi ugrupowaniami gwarowymi.

W niniejszym artykule używam standardowej transkrypcji IPA. Koniecznych jest tu kilka drobnych uwag. Litery [S, z, ts, dz] odpowiadają polskim $s z, \dot{z}, c z, d \dot{z}$, znaki [ $\int, 3, \mathrm{t} \int$, d3] symbolizują zaś spółgłoski mniej lub bardziej wyraźnie zmiękczone. Afrykaty oznaczam za pomocą kombinacji typu [ts], w przypadku połączeń zwartej ze szczelinową używam natomiast zapisu [t-s]. Taki sam sposób notacji stosuję do rozróżniania dyftongów od połączeń dwóch samogłosek. Symbol [ọ] reprezentuje dźwięk tożsamy z polskim $y$. Litery [a] używam, zgodnie ze standardem, na oznaczenie samogłoski przedniej. Barwę centralną (czy ogólnie nieprzednią i nietylną) oznaczam symbolem [ä].

W razie znaczniejszej sprzeczności obecnej wymowy z zastosowanym oznaczeniem będę stosował gwiazdkę (np. */e/). Zapis typu */e/ oznacza nie tylko brzmienie rekonstruowane, stosuję je również jako synonim sformułowania „kontynuant(y) */e/”, „fonem kontynuujący */e/" itp.

Dla oszczędności miejsca stosuję w części zasadniczej następujące skróty: PK (=północnokaszubski, północne Kaszuby, północna kaszubszczyzna), CK (=centralnokaszubski, centralne Kaszuby, centralna kaszubszczyzna), ZCK (=zachodnio-centralnokaszubski, zachodnio-centralne Kaszuby, zachodnio-centralna kaszubszczyzna), WCK (=wschodniocentralnokaszubski, wschodnio-centralne Kaszuby, wschodnio-centralna kaszubszczyzna), S (=Strzepcz, strzepski). Oczywiście w zasadniczej części pracy interesująca nas gwara nie wchodzi w zakres żadnego z określeń, które na podstawie dotychczasowych opisów można by do niej odnieść.

Rozpocznę od krótkiego przedstawienia samych wniosków dotychczasowych badaczy na temat miejsca gwary luzińskiej wśród gwar kaszubskich. Trzeba tu mieć na uwadze, że

\footnotetext{
${ }^{5}$ W opisie zjawisk samogłoskowych w niniejszym artykule opieram się na tym właśnie opracowaniu.
} 
nie tylko ostateczne przyporządkowanie tej czy innej gwary do większych ugrupowań gwarowych, ale również kryteria podziału kaszubszczyzny na zespoły dialektalne są w poszczególnych opracowaniach różne. Friedrich Lorentz (1927-1937: 15-16) klasyfikuje gwarę luzińską jako północnokaszubską. Kazimierz Nitsch (1903: 223) uznaje ją za centralnokaszubską. Zdzisław Stieber (1951: 507) charakteryzuje opracowanie Nitscha jako „opis [...] dialektu północno-kaszubskiego”. Paweł Smoczyński (1955: 84-85) stwierdza natomiast, iż ocena Nitscha co do klasyfikacji gwary luzińskiej - wbrew Lorentzowi - jest słuszna. Mają to przy tym potwierdzać nowe właściwości gwary. Zuzanna Topolińska $\mathrm{w}$ opracowaniu Teksty gwarowe centralnokaszubskie z komentarzem fonologicznym uwzględnia również obszar gwary luzińskiej, choć w pewnych fakultatywnych i stosunkowo rzadkich zjawiskach dostrzega tu nawiązania do kaszubszczyzny północnej (Topolińska 1967: 87, 120). W historycznej fonologii kaszubszczyzny badaczka zajmuje już stanowisko, iż gwara luzińska jest północnokaszubska (Topolińska 1974: 99, 134). Kwiryna Handke (1979: 118-119) na podstawie danych AJK (AJK 1964-1978) stwierdza przynależność gwary luzińskiej do obszaru północnokaszubskiego, choć najbardziej wysunięta na południe wieś (stanowiące enklawę luzińską Kętrzyno) leży na obszarze przejściowym pomiędzy północną a centralną kaszubszczyzną. Część punktów luzińskich należy również do zespołu gwar obejmujących niemal całą zachodnią rubież kaszubszczyzny. Jerzy Treder (199: 288) zgadza się z wnioskami P. Smoczyńskiego. Jak widzimy, miejsce gwary luzińskiej wśród gwar kaszubskich postrzegane jest różnie, nawet przez jednego i tego samego autora.

Przejdźmy do omówienia konkretnych kryteriów, przyjmowanych przez dotychczasowych badaczy. Podana mimochodem charakterystyka Stiebera nie jest w żaden sposób rozwinięta czy uargumentowana. W przypadku opracowania K. Handke ilość przesłanek jest znaczna, ale nie są one wyszczególnione (autorka uwzględniła przy tym dane ze wszystkich poziomów systemu językowego). Nie sposób się więc do ocen tych autorów bezpośrednio odnieść. W pozostałych przypadkach kryteria są jednak jasno wyartykułowane.

W starszych publikacjach przywoływane są w pierwszym rzędzie cechy prozodyczne. K. Nitsch, odwołując się chyba do starszych opracowań F. Lorentza (1901: 110; 1903: 168-170, 385) ${ }^{6}$, stwierdza przynależność gwary luzińskiej do obszaru centralnokaszubskiego ze względu na brak w niej opozycji akcentu melodycznego (Nitsch 1903: 223, 241). Później wyraża on wyraźny sceptycyzm co do istnienia dwóch rodzajów takiego akcentu na północy (pomimo eksplicytnej uwagi, iż ,nie myśli bynajmniej poddawać [go] w wątpliwość [...]”). Ponadto z racji na wtórny w zasadzie charakter (uzależnienie od konkretnego fonemu samogłoskowego poza jednym tylko wyjątkiem) K. Nitsch neguje niemal zupełnie zarówno diachroniczną, jak i synchroniczną istotność przyjmowanej przez F. Lorentza opozycji (Nitsch 1908: 127). Zresztą analiza Willema Stokhofa wykazuje jednoznacznie, że wyjątek stwierdzony przez K. Nitscha jest wyłącznie pozorny, opozycja postulowana przez F. Lorentza jest więc absolutnie wtórna i nieistotna zarówno z diachronicznego, jak i synchronicznego (fonologicznego) punktu widzenia (Stokhof 1973a:

\footnotetext{
${ }^{6}$ Można powątpiewać, czy K. Nitsch znał te akurat teksty (zwłaszcza Slovinzische Grammatik), tworząc i publikując swe opracowanie (a właściwie wstęp do niego). Bez wątpienia jednak odnosi się on tu do wyrażonych w nich interpretacji F. Lorentza, które mógł znać skądinąd.
} 
136-138; 1973b 133-134). Z. Stieber stwierdza zresztą dosadnie, że „intonacje kaszubskie istniały tylko w fantazji Lorentza" (Stieber 1957: 364). Badacz sugeruje przy tym, iż wrażenie istnienia akcentu melodycznego może wynikać z wyraźnego podniesienia tonu towarzyszącego silnemu akcentowi dynamicznemu. Hipotezę tę potwierdzają moje obserwacje z gwary żarnowieckiej (w przypadku akcentowanych samogłosek tylnych, inherentnie nad wyraz długich, rzeczywiście niejednokrotnie zwraca na siebie uwagę przebieg F0, który przy dokładniejszej analizie okazuje się jednak nie mieć charakteru systemowego). Kryterium konturu tonu podstawowego samego w sobie jest więc bezwartościowe. Istotna może tu być wyłącznie - i to tylko w sensie fonetycznym - siła akcentu wraz z towarzyszącymi mu innymi cechach prozodycznymi.

Friedrich Lorentz (1927-1937: 15-16, 18) za podstawową różnicę pomiędzy kaszubszczyzną północną (do której zalicza interesujący nas obszar) a południową uznaje istnienie w tej pierwszej „stałych różnic iloczasowych”, wyróżniając trzy stopnie długości. Opis K. Nitscha (227) pozwala dla gwary luzińskiej przyjąć marginalną opozycję iloczasową właściwie tylko dla $i$. W istocie $\mathrm{w}$ większości przypadków długości opisywane przez F. Lorentza były uwarunkowane wyłącznie charakterem samogłoski, miejscem akcentu i budową sylaby, będąc w związku z tym wtórne i nieistotne zarówno z diachronicznego, jak i synchronicznego punktu widzenia, przynajmniej dla leksyki rodzimej (Stokhof 1973a: 136, Stokhof 1973b: 28). Wyjątek stanowiły tylko $i$ i $u$, choć również tu opozycja była na przełomie XIX i XX wieku na etapie zaniku i nie dotrwała w najmniejszej mierze do połowy 20. wieku (Stieber 1951; Stieber 1957). F. Lorentz był zresztą ostro krytykowany za opis iloczasu kaszubskiego. K. Nitsch pisze, odnosząc się do Slovinzische Grammatik: „Wielką nieufność budzi ustęp o iloczasie. Autor rozróżnia mianowicie [...] sześć gatunków iloczasu. Gdy się przypomni, jak dalece wahają się, a czasem i zacierają, nawet przy badaniu za pomocą przyrządów, tak wybitne różnice iloczasowe jak czeskie [...] to trudno nie wyrazić podejrzenia, że tych sześciu stopni iloczasu autor nie słyszał, lecz wykombinował je sobie na podstawie fizjologicznych i historycznych różnic danych głosek, wykombinowawszy zaś, sam w ich istnienie uwierzył" (Nitsch 1908: 127). Z. Stieber stwierdza: „Wiadomości o prozodii dialektów kaszubskich, rozpowszechnione wśród ogółu językoznawców-slawistów są nie tylko nieścisłe, ale nieraz po prostu błędne. Zawinił tu głównie [...] Friedrich Lorentz, którego talent dialektologa zawiódł właśnie przy obserwacji zjawisk prozodii" (Stieber 1957: 362). Kwestia iloczasu jest więc niewątpliwie nieistotna $\mathrm{z}$ dzisiejszego punktu widzenia. W sensie diachronicznym może być ona istotna w zasadzie tylko jako zachowanie wspólnego archaizmu, które oczywiście nie może być mocnym argumentem w dyskusji o przynależności dialektalnej.

Kazimierz Nitsch zwraca uwagę na „znaczne uproszczenie akcentu przyciskowego, tak bogatego u Bylaków”, dodając, iż jego właściwości „zbliżają go do terytoryum środkowej kaszubszczyzny" (Nitsch 223, 241). Jest to kryterium potencjalnie istotne do dnia dzisiejszego, choć należy tu mieć na uwadze, że niewątpliwe ugrupowania dialektalne na Kaszubach nie zawsze są jednolite co do systemu akcentowego (Jocz 2015a).

Jako kolejne kryterium K. Nitsch (1903: 223) wymienia brak zaniku $g$ w zaimkowej i przymiotnikowej końcówce -(e/é)gò. Rzecz ta wydaje mi się szczegółem, poza tym należy ona przynajmniej częściowo do morfologii. Zresztą sam autor kilka stron później stwierdza w gwarze luzińskiej wymowę tych form bez $g$, choć ma być ona rzadka czy wręcz sporadyczna (Nitsch 1903: 231). 
Następnie K. Nitsch (1903: 223) mówi o mniejszym niż na północy zakresie $\ddot{e}$, zwracając uwagę na brak przejścia $u \mathrm{w} \ddot{e} \mathrm{w}$ końcówkach. Znów jest to cecha $\mathrm{w}$ znacznej przynajmniej mierze morfologiczna.

Paweł Smoczyński (1955: 84-85) powtarza i potwierdza wnioski K. Nitscha, zwracając uwagę, iż również nowe cechy gwary, przez niego zaobserwowane, zbliżają gwarę luzińską do strzepskiej, niewątpliwie centralnokaszubskiej. Nawiązania te mają jednak wyłącznie charakter morfologiczny, poza tym są nieliczne i zwykle chodzi tu o podobieństwa, a nie pełną tożsamość (Smoczyński 1955: 82-84). W kwestiach fonetycznych (uwzględniam tu tylko eksplicytne uwagi) badacz notuje natomiast nierzadko nie tylko archaizmy, ale również tendencje rozwojowe odróżniające gwarę luzińską od strzepskiej i nawiązujące do północnej kaszubszczyzny jak ograniczenie czy zanik afrykatyzacji miękkich tylnojęzykowych, dyftongizację samogłosek średnich pod akcentem czy też zanik samogłosek nieakcentowanych (Smoczyński 1955: 81, 82).

Jerzy Treder twierdzi, że opisane przez P. Smoczyńskiego zmiany ,wynikły z rozwoju wewnętrznego i potwierdzają słuszność zaliczenia przez Nitscha gwary luzińskiej do środkowokaszubskich, czego nowym dalszym argumentem jest jej zbliżenie się do strzepskiej" (1999: 288). Wyliczone na tej samej stronie cechy - stanowiące eksplicytnie podstawę zacytowanego wniosku - warte są bardziej szczegółowego omówienia (zaznaczyć tu należy, że opis P. Smoczyńskiego został przez J. Tredera miejscami silnie streszczony, czasem aż za bardzo).

W pierwszym rzędzie J. Treder wymienia ogólne uproszczenie akcentu i ograniczenie jego ruchomości, wręcz tendencję do akcentu inicjalnego (podając jako przykład zanik oksytonezy u przymiotników typu dobri), por. wyżej. Rzecz ta bez wątpienia wymaga uwagi.

Wycofanie się przedniej wymowy */o/ po niemarginalnych znalazło się tu chyba przez przypadek. Zjawisko to bez wątpienia było umotywowane wpływem sąsiednich gwar, nie łączy jednak gwary luzińskiej z żadną z sąsiednich gwar bardziej niż z jakąkolwiek inną.

Następnie J. Treder wymienia wycofanie się ściągnięć typu [da] 'dała' i ['nimjju] 'nie miał'. Trudno się tu jednak dopatrywać szczególnego związku z którąkolwiek z sąsiednich gwar. Ściągnięcia takie do dziś wyraźnie dominują nad wymową nieściągniętą (wbrew P. Smoczyńskiemu (1955: 79) również w połączeniu *[iw]). Choć gwary CK znają również podobne zjawiska, to nie do porównania jest tu ani zakres objętych połączeń, ani częstotliwość.

Kolejną cechą ma być tylna wymowa $\ddot{e}$. Zagadnieniem tym zajmę się, jednak od razu zaznaczę, że problematyczna jest tu charakterystyka luzińskiego $\ddot{e}$ jako tylnego (Jocz 2016), poza tym również na centralnych Kaszubach wymowa nie jest całkowicie jednolita (Jocz 2013: 66, 192-193, 196, 197, 200).

Kwestię dyftongicznej wymowy */o/ po marginalnych J. Treder referuje bardzo skrótowo, nie w pełni oddając sens słów P. Smoczyńskiego. Przyjrzę się temu zagadnieniu w dalszej części pracy, choć już tutaj napomknę, że również ten punkt jest wątpliwy (w rzeczywistości wymowa luzińska nie pokrywa się z najbardziej reprezentatywną wymową w centralnej kaszubszczyźnie).

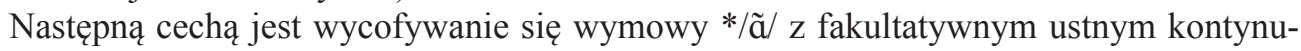
antem typu $[\varepsilon]$ i upowszechnienie się [a]. Ta uwaga J. Tredera jest bardzo wartościowa, bowiem P. Smoczyński nie omawia tego zjawiska w kontekście przynależności gwary luzińskiej do północnej lub centralnej kaszubszczyzny. 
Na końcu Jerzy Treder zwraca uwagę na brak afrykatyzacji miękkich tylnojęzykowych na [t $\int$, dz] (tutaj znów nie referując P. Smoczyńskiego w pełni precyzyjnie). Zagadnienie to jest istotne i omówię je w dalszej części pracy, tu jednak podkreślę, że cecha ta wyraźnie odróżniałaby gwarę luzińską od centralnej kaszubszczyzny, a nie do niej zbliżała.

W Tekstach... Zuzanna Topolińska jako północną granicę centralnej kaszubszczyzny do której zalicza gwarę luzińską - określa występowanie ,jjednolitego systemu wokalicznego, identycznego w zasadzie w pozycji pod- i pozaakcentowej" (Topolińska 1967: 87). Redukcję systemu samogłoskowego poza akcentem określa ona zresztą jako cechę „,wyróżniającą, definicyjną" PK (Topolińska 1969: 67). Badaczka zauważa co prawda, że również na obszarze centralnym i południowym dochodzi do przypadków uzależnienia wokalizmu od akcentu, ale tu ma mieć on charakter fakultatywny i alofoniczny, podczas gdy na północy mamy mieć do czynienia z ograniczeniami ściśle kombinatorycznymi i fonologicznymi (Topolińska 1967: 87). W komentarzach szczegółowych Z. Topolińska podaje, iż na północy uwzględnionego przez nią obszaru (czyli m.in. w gwarze luzińskiej) obserwuje się dyftongiczną wymowę samogłosek średnich, co stanowi niewątpliwe „nawiązanie do północnokaszubskich różnic między wokalizmem pod- i pozaakcentowym” (Topolińska 1967: 120). Oba te zjawiska są bardzo ważne i poświęcę im należytą uwagę w dalszej części pracy.

Jak już wspomniałem, w A Historical Phonology... Z. Topolińska przyjmuje zupełne inne kryteria i dochodzi do odmiennych wniosków co do miejsca gwary luzińskiej, przyporządkowując ją do północnej kaszubszczyzny.

Pierwszym zjawiskiem łączącym gwarę luzińską z północną kaszubszczyzną - a dokładniej z jej zachodnią częścią włącznie z dialektem słowińskim - jest uprzednienie ${ }^{7}$ / / / po wszystkich spółgłoskach, które doprowadziło ostatecznie do powstania najbardziej charakterystycznej cechy luzińskiej, czyli wymowy przedniej nielabializowanej po niemarginalnych (Topolińska 1974: 79, 97-99, mapka na s. 102) ${ }^{8}$. Rzecz to bez wątpienia bardzo ważna. Z racji jednak na to, że wszystkie pozostałe gwary znające to zjawisko (abstrahując od ostatecznego rezultatu fonetycznego) wymarły, z punktu widzenia klasyfikacji gwar kaszubskich jest to dla nas cecha o znaczeniu wyłącznie historycznym ${ }^{9}$. Z dzisiejszego punktu widzenia jest to osobliwość gwary luzińskiej na tle wszystkich pozostałych gwar kaszubskich i synchronicznie nie możemy tu mówić o cesze północnokaszubskiej.

Drugim punktem stycznym gwary luzińskiej z gwarami północnokaszubskimi jest rozwój */u, u:/, odmienny niż w centralnej kaszubszczyźnie (Topolińska 1974: 92-96), por. (Lorentz 1925: 51-54; Lorentz 1911: 9-10). Jest to znów cecha ważna, ale wyłącznie o znaczeniu historycznym. Z dzisiejszej perspektywy nie sposób byłoby jej stwierdzić, bez szczegółowych opisów F. Lorentza nigdy byśmy się o niej nie dowiedzieli (Topolińska 1974: 95). Trudno więc uwzględniać tę cechę w opisie współczesnych stosunków dialektalnych.

7 Z. Topolińska stosuje tu określenia stricte fonologiczne (co nieco zaskakujące, definiowane akustycznie). Referując jej opis, przekładam je na fonetyczne.

${ }^{8}$ Zmiana ta niemal całkowicie się wycofała, jednak w pozycjach, gdzie się zachowała, trzyma się do dziś dość dobrze (Jocz 2016).

9 Trzeba tu podkreślić, że gwary mogą w toku rozwoju zmieniać swą przynależność do szerszych ugrupowań dialektalnych. 
Jako kolejną istotną cechę Z. Topolińska podaje rozwój */a:/ w samogłoskę, oznaczaną przez nią symbolem $\omega$ (czyli samogłoskę niewysoką i nieniską, centralną czy tylno-centralną, labializowaną). Wymowa taka ma łączyć gwarę luzińską z leżącymi od niej na wschód gwarami północkaszubskimi oraz gwarą jastarnicką. Badaczka zaznacza przy tym, iż interesującemu nas obszarowi obcy jest centralnokaszubski rozwój */a:/ w kierunku szeregu przedniego i jego delabializacja oraz analogiczna i równoległa zmiana */u/. Wszystko to utożsamiać ma wokalizm gwary luzińskiej z systemem typowym dla północnej kaszubszczyzny (Topolińska 1974: 96-100, mapka na s. 102). Zagadnienie wymowy */a:/ jest niewątpliwie istotne, natomiast ujęcie Topolińskiej w wielu aspektach okazuje się dość problematyczne (zacznijmy choćby od tego, iż już samo centralne czy tylno-centralne brzmienie $\omega \mathrm{w}$ gwarze luzińskiej jest fikcją). Rzecz omówię obszernie poniżej.

Jak widzimy, tylko część z przywoływanych w dotychczasowej literaturze kryteriów jest potencjalnie użyteczna dla określenia synchronicznego statusu gwary luzińskiej wśród gwar kaszubskich. Zreferowane kryteria nie wyczerpują jednak w żadnym wypadku zagadnienia, zwłaszcza w zakresie nowszych zmian.

\section{Zjawiska wokaliczne}

\subsection{Wymowa *[i, i]}

W dialektologii polskiej przyjmuje się dość powszechnie, iż w gwarach północnej Polski - w tym w gwarach kaszubskich - doszło do całkowitej identyfikacji fonetycznej *[i] i *[i]. Wspólnym kontynuantem obu głosek ma być [i], przy czym spółgłoski przed *[i] mają być miękkie, a przed *[i] - twarde (Dejna 1981: mapa 39; Dejna 1993: 150-151, mapa 25; Urbańczyk 1984: 19; Nitsch 1955: 5; Nitsch 1957: 28). Że jest to - przynajmniej w stosunku do niektórych gwar polskich - uproszczenie, i to nadmierne, wiadomo od dawna (patrz np. (Friedrich 1939: 20-21). O tym, że w CK, zwłaszcza w ZCK, na miejscu *[i] występuje głoska wyraźnie scentralizowana w stosunku do [i] (czyli prawdopodobnie coś w rodzaju [I]), dowiadujemy się już od Stefana Ramułta (1893: XXV) i Friedricha Lorentza (1911: 6-7). Autorzy AJK stwierdzają zwłaszcza na obszarze gwar ZCK (w wyrazach jak syn 'syn' czy dim 'dym') wręcz wymowę z [э̣] (AJK 14: 103-104). Różnego rodzaju warianty scentralizowane (zwykle jednak w rodzaju [I]) rejestruje również materiał centralnokaszubski opracowany przez Zuzannę Topolińską $(1967)^{10}$. Obecnie na obszarze ZCK (należy tu również w pełni S) w zależności od kontekstu lewostronnego barwa [э̣] (głównie na miejscu $*[i]$, ale w pewnych szczególnych pozycjach i przypadkach również na miejscu *[i]) jest absolutnie dominująca, (bardzo) częsta lub obecna. W gwarach WCK wymowa taka jest ogólnie wyraźnie rzadsza, ale również występuje regularnie w tożsamych kontekstach, jak na zachodzie (Jocz 2013: 35-44). W gwarze luzińskiej zjawiska takiego brak. Panuje tu wymowa wysoka i przednia (oczywiście w jej ramach możliwe są wymowy nieco scentralizowane), a poprzedzająca spółgłoska może ulec zmiękczeniu, np. syn [sin]

${ }^{10}$ Dystrybucja samogłoski [i] i głosek scentralizowanych w stosunku do [i] pozostaje przy tym w bardzo wyraźnym związku z pochodzeniem konkretnej samogłoski z *[i] lub *[i], z którego to faktu Z. Topolińska nie wyciąga jednak koniecznych konsekwencji dla opisu fonologicznego (Jocz 2012: 148-149). 
'syn', dim [diim] 'dym'. Wymowa otwarta [I, э̣] pojawiać się może tylko po twardych (lub stwardniałych) w wygłosie, np. dłudżi ['dwug९̣] 'długi' (ograniczenie takie nieznane jest CK, nie chodzi tu więc o genetycznie tożsame procesy) ${ }^{11}$.

Zachowanie tu w zasadzie barwy typu [i] oraz rozszerzona wymowa w wygłosie po twardych łączy gwarę luzińską synchronicznie z północą kaszubszczyzny. Z diachronicznego punktu widzenia nie sposób jednak dać ogólnej i jednoznacznej odpowiedzi na pytanie, czy mamy tu do czynienia z archaizmem (archaizmami) czy innowacją (innowacjami). Wymowa wyraźnie scentralizowana na miejscu *[i] po wargowych w gwarach CK (np. bik [bọk]) może być bowiem rzeczywistym (bezpośrednim) archaizmem, ale niewykluczone, że jest to w jakimś przynajmniej stopniu wynik procesu wtórnego, podkreślającego opozycje fonologiczne ${ }^{12}$. W przypadku pozycji po /t, d, s, z, c, dz/ (np. syn [sọn]) brak czynników fonologicznych, co przemawiać by mogło za bezpośrednim archaizmem. Nie jest jednak pewne, czy rozwój po wargowych i zębowych nie był w pewnym przynajmniej zakresie niezależny (częstotliwość [i] i [ọ], które zarówno po wargowych, jak i po zębowych występują obocznie ${ }^{13}$, różni się w obu tych kontekstach). Sama barwa [э̣] lub przynajmniej jej rozpowszechnienie jest w obu przypadkach innowacją, dawniej występowało tu lub dominowało [I] (rolę mógł tu odegrać wpływ polszczyzny). Pojawianie się wymowy scentralizowanej na miejscu *[i] po /1/ (np. pôli ['pọlọ] 'pali') na CK jest zaś niewątpliwą innowacją, przy czym stosunkowo dawną (Lorentz 1911: 6-7). Całkiem nowym zjawiskiem, które ogarnęło w pełni całą CK, a najsłabszych przejawów którego nie stwierdziłem w Luzinie, jest natomiast rozwój *[i] na [э̣] po *[r] (np. zdrzi [zd-z९̣] 'patrzy'). Mamy tu więc do czynienia z kompleksem zjawisk o nieco różniących się uwarunkowaniach i nie zawsze tożsamej chronologii, przy czym dokładny przebieg wszystkich procesów nie jest nam znany. Nie będą chyba jednak nadużyciem stwierdzenia, iż (1) gwara luzińska - w przeciwieństwie do gwar CK (zwłaszcza sąsiadujących z nią bezpośrednio ZCK) i zgodnie z gwarami niewątpliwie PK - uczestniczyła konsekwentnie w ścieśnieniu *[i] na [i], (2) nie uczestniczyła w różnego rodzaju - zarówno starszych i bardzo ,świeżych" - procesach centralizacji i opuszczania kontynuantów *[i] i *[i], typowych dla gwar CK, (3) uczestniczyła w pewnych procesach do centralizacji i opuszczania *[i] i *[i], typowych dla gwar PK.

11 Na zjawisko to zwracam uwage jeszcze raz w opisie redukcji.

12 Nie budzi najmniejszych wątpliwości, iż dawne połączenia *[Pji] i *[Pi] nigdy nie utożsamiły się fonologicznie, rozwijając się odpowiednio w sekwencje /Pji/ i /Pi/. Początkowo opozycja pomiędzy nimi mogła być wyrażana fonetycznie - jak to ma miejsce czasem i dzisiaj - wyłącznie lub głównie jako przeciwstawienie [P( $\left({ }^{\mathrm{j}}\right)$ ji] i [P(j)i], por. (Nitsch 1906: 167-168; Furdal 1964: 22-23, 33-34). Oczywiście hipoteza o wtórnym pojawieniu się scentralizowanej wymowy u *[i] zakłada większą ilość zmian, w związku z czym - nie dysponując jednoznacznymi dowodami jej prawdziwości - musielibyśmy odrzucić ją zgodnie z zasadą brzytwy Ockhama. Dotychczasowe opisy fonetyki kaszubskiej - zwłaszcza te ogólne - dowodów takich wbrew pozorom nie dostarczają. Twierdzenie o całkowitym zlaniu się *[i] i *[i] w samogłosce [i] jest bowiem, jak widzimy, w pewnej przynajmniej mierze mitem dialektologicznym i opisy przyjmujące implicytnie lub eksplicytnie taki rozwój traktować należy z pewną ostrożnością.

13 Np. obok wymowy bik [bọk] 'byk' możliwa jest (u jednego i tego samego informatora) również wymowa ['bjik]. W przypadku *[i] mamy natomiast zawsze [i], np. bic ['bjits] 'bić'. Różnicę tę - niewątpliwie o charakterze fonologicznym - ignoruje pisownia kaszubska. 


\subsection{Wymowa *[e:]}

Dawne *[e:] $]^{14}$ wymawiane było początkowo w całej kaszubszczyźnie (jak również w gwarach polskich) niewątpliwie jak samogłoska średnia zamknięta typu [e]. F. Lorentz (1927-1937: 204-207) obserwuje taką właśnie wymowę jeszcze we wszystkich niemal gwarach kaszubskich. Na samej północy (w Jastarni) na miejscu [e] występować mają dyftongi [ei, عi], natomiast w południowej kaszubszczyźnie szerzyć się ma wymowa [९̣], tym częstsza, im dalej na południe. Realizacje typu [э̣] występować mają również w części gwar PK, ale tu tylko poza akcentem. Materiały Z. Topolińskiej (1967) dokumentują obecność w CK [e] i barw pokrewnych, ale w zasadzie odmiennych od [ọ]. Współcześnie w gwarach CK obserwujemy niemal wyłącznie wymowę [э̣]. Wymowa [e] (a dokładniej [e]) jest niezwykle rzadka, na tyle, że trudno nawet jednoznacznie stwierdzić, czy jest to jakiś samodzielny wariant wymowy, nieuwarunkowany czynnikami wtórnymi. Tylko w S notowałem u starszych informatorów obok absolutnie dominującego [э̣] również rzadką wymowę dyftongiczną typu [ọe]. Na północy kaszubszczyzny panuje obecnie nadal wymowa zamknięta i (przynajmniej w gwarze żarnowieckiej) dyftongiczna ([eị]). Środkiem ciężkości jest tu poziom średni zamknięty, nawet ze skłonnością do wymowy nieco podniesionej w stosunku do niego. W gwarze luzińskiej */e:/ realizowane jest przeciętnie jak samogłoska przednia, a co do poziomu obniżona wysoka, półwysoka lub podwyższona średnio-zamknięta. Najbardziej typowe warianty można oznaczyć jako [ị, ê, İ]. Możliwa jest tu co prawda wymowa bardziej scentralizowana typu [I, ९̣], ale są to realizacje niezbyt częste i leżące na absolutnym skraju rozkładu.

Gwara luzińska (1) nie uczestniczyła więc $\mathrm{w} \mathrm{CK}^{15}$ innowacji, polegającej na zmianie [e] na [э̣] i (2) wykazuje tendencję, wspólną z gwarami PK, do pewnego podwyższenia kontynuantów *[e:]. W obu przypadkach mamy do czynienia z procesami dość świeżej daty.

\subsection{Wymowa *[e]}

Pierwotnie kontynuantem $e$ krótkiego we wszystkich gwarach kaszubskich była niewątpliwie samogłoska przednia, poziomu średniego otwartego, czyli $[\varepsilon]$. Tak też było zapewne w dialektach polskich, współcześnie w języku ogólnopolskim panuje jednak wymowa wyraźnie scentralizowana (Sawicka 2007: 307). Tego typu wymowa ${ }^{16}$ dominuje również współcześnie w gwarach CK (łącznie ze S). Pojawia się tu również wymowa jaśniejsza, czyli wybitnie przednia $\mathrm{i}$ ewentualnie nieco podwyższona oraz wymowa [э̣] w sąsiedztwie twardych koronalnych. Tego typu realizacje są jednak fakultatywne, ogólnie rzadkie i uwarunkowane konkretnym kontekstem fonetycznym. W gwarach PK stwierdzano już dawniej wymowę ogólnie wyższą niż w ogólnej polszczyźnie, a ponadto tendencję do dalszego zwężenia i dyftongizacji (Topolińska 1969: 83). W gwarze żarnowieckiej stwierdziłem

\footnotetext{
${ }^{14}$ Rozpatrywać tu będę tylko pozycję po spółgłoskach twardych.

${ }^{15}$ Innowacja ta mogła dotrzeć z południa lub wykształcić się niezależnie. Być może rolę odegrał tu wpływ języka polskiego (chodziłoby tu o usuwanie barw obcych polszczyźnie).

${ }^{16} \mathrm{~W}$ pierwszej kolejności omawiam pozycję po niepalatalnych. Wymowę po palatalnych opisuję poniżej.
} 
całkowite zwycięstwo tej tendencji, czyli konsekwentne podniesienie i dyftongizację * $[\varepsilon]$, rezultat której można oznaczyć jako [eָe]. W Jastarni stwierdziłem podwyższenie (z centralizacją) do [९̣], podobnie w Chłapowie (z pewnymi ograniczeniami u młodszej informatorki). Nitsch (1903: 224) zrównuje luzińskie $e$ z polskim. Jednak już F. Lorentz dostrzega tu pewną tendencję do wymowy dyftongicznej i bardziej zamkniętej pod akcentem (Lorentz 1927-1937: 182, 184-185, 186). Z. Topolińska (1967: 120) stwierdza na obszarze gwary luzińskiej zarówno wymowę podwyższoną, jak i dyftongiczną, dostrzegając tu nawiązanie do gwar północnokaszubskich. W tekstach warianty takie występują obok monoftongicznej wymowy średniej otwartej (Topolińska: 108-112). We współczesnym materiale luzińskim stwierdziłem wyłącznie wymowę wyższą od ogólnopolskiej, zazwyczaj zdecydowanie. Najbardziej typowa barwa to samogłoska bliska [э̣] lub wręcz jemu tożsama. Czasami pojawia się na jej miejscu dyftong typu [3e].

W gwarze luzińskiej zaszło więc - w odróżnieniu od gwar CK, a zgodnie z gwarami PK - konsekwentne i niezależne od kontekstu fonetycznego zwężenie $*[\varepsilon]$. Jest to przy tym zjawisko stosunkowo nowe. Gwary CK objął zresztą w tym samym czasie proces zgoła odwrotny, czyli tendencja do zaniku wariantów nieco podwyższonych w stosunku do poziomu średniego otwartego i wymowy ogólnie mniej peryferycznej ${ }^{17}$.

Na osobną uwagę zasługuje pozycja po miękkich (palatalnych). Już K. Nitsch (1907: 178) stwierdził tu w gwarze luzińskiej wariant bardziej „palatalny”. F. Lorentz (19271937: 182) pisze o przejściu *[ع] w danej pozycji w [эฺ], które objęło oprócz gwary luzińskiej również część gwar PK. Od czasów F. Lorentza uległa pewnemu rozszerzeniu terytorialnemu, stwierdziłem ją bowiem dość powszechnie również w S (np. pies [pjjọs, pjjes] 'pies'). Nie notowałem natomiast takiej wymowy w innych gwarach CK. Zwężenie po palatalnych jest więc procesem odrębnym od wzniesienia $*[\varepsilon] \mathrm{w}$ pozostałych pozycjach. Po pierwsze ma ono inną chronologię, a mianowicie jest wcześniejsze (absolutnego czasu jego wykształcenia się w gwarze luzińskiej podać nie możemy, ponieważ stwierdzono je już w najstarszych jej opisach). Po drugie inne są jego uwarunkowania, da się ono bowiem opisać jako banalne zjawisko asymilacyjne. Dzisiaj w Luzinie $e$ wszędzie brzmi tak samo (inaczej niż w S) i bez starszych opisów nie moglibyśmy wykazać, że są to dwie oddzielne zmiany głosowe. Zjawisko to możemy opisać jako (lokalny) proces PK, który uległ rozszerzeniu na część sąsiednich gwar, w tym - chyba stosunkowo niedawno - na przynajmniej jedną niewątpliwie CK.

\subsection{Wymowa *[a] (nie przed $[\mathrm{N}])$}

Zarówno uniwersalia fonetyczne, jak i znane nam czy dające się łatwo zrekonstruować fakty z zakresu dialektologii i fonetyki historycznej polszczyzny i kaszubszczyzny pozwalają nam wychodzić z założenia, iż a krótkie było początkowo - przynajmniej do czasu zasadniczych zmian jakościowych (głównie ścieśniania) kontynuantów a długiego i w gwarach ostatecznie rozróżniających oba dźwięki - samogłoską centralną (czy nawet przedniocentralną) i nielabializowaną. Ewentualny dalszy rozwój barwy *[a] następować mógł na skutek tendencji spontanicznych jak i uwarunkowanych systemowo. Lorentz niepewnie

\footnotetext{
${ }^{17}$ Niewykluczone, że tendencja ta uwarunkowana była wpływem polszczyzny ogólnej.
} 
stwierdza, iż *[a] charakteryzuje się wymową nieco bardziej tylną na całej północy. Na samej północy (w Dębkach na obszarze gwary żarnowieckiej) zauważa ponadto zarodkową tendencję do dyftongizacji na [äŭ] (Lorentz 1927-1937: 170). Z. Topolińska dostrzega fakultatywny wariant labializowany (Topolińska 1969: 83), w opracowanych przez nią tekstach nie jest on jakoś szczególnie częsty (np. w Wierzchucinie i Nadolu ma on udział ok. $4,7 \%$ realizacji akcentowanych). W gwarze żarnowieckiej (u dwóch informatorów reprezentujących pokolenie starsze i średnie) zanotowałem konsekwentną wymowę akcentowanego *[a] jako wybitnie tylnego i zaokrąglonego *[p]. W Chłapowie zaobserwowałem zarówno wymowę wyraźnie ciemniejszą od ogólnopolskiej i fakultatywnie labializowaną ( $\mathrm{u}$ informatora $\mathrm{w}$ wieku średnim), jak i wymowę tożsamą z ogólnopolską (u informatora w wieku młodszym). W Jastarni u osoby starszej zanotowałem wahania pomiędzy wymową zdecydowanie tylną (bez labializacji) i centralną lub jej bliską, u osoby w wieku średnim zaś wystąpiła wymowa centralna lub jej bliska (w dwóch przypadkach pojawiła się u tego informatora wymowa [o], która - jeżeli nie jest lapsusem - może być próbą naśladowania wymowy archaicznej). Można podejrzewać, że wszystkie gwary niewątpliwie PK stosunkowo niedawno $^{18}$ objęła silna tendencja do ciemnej (i labializowanej) wymowy *[a $]^{19}$. Następnie tendencja ta - przynajmniej na części obszaru PK - zaczęła się wycofywać, zapewne wskutek wpływu ogólnej polszczyzny. W gwarach CK stwierdziłem we wszystkich grupach wiekowych praktycznie wyłącznie wymowę centralną, tożsamą z ogólnopolską. Poświadczenia barwy nieznacznie ciemniejszej (i nielabializowanej) są wyjątkowe i w ogólnym opisie pomijalne. Przejdźmy do stanu w gwarze luzińskiej. K. Nitsch (1903: 224) zrównuje wymowę *[a] w Luzinie z ogólnopolską. Przytoczona powyżej ogólna uwaga F. Lorentza co do wymowy ciemniejszej na północy odnosi się zgodnie z jego klasyfikacją gwar kaszubskich również do gwary luzińskiej. Z. Topolińska ogólnie zwraca uwagę na fakultatywny wariant zaokrąglony (Topolińska 1967: 114), który pojawia się zresztą $\mathrm{w}$ transkrypcjach tekstów $\mathrm{z}$ interesującego nas obszaru. W moim materiale luzińskim *[a] charakteryzuje się właściwie zawsze brzmieniem ciemniejszym od ogólnopolskiego i CK. Najczęściej wystąpiło tu centralno-tylne [ạ], rzadziej wyraźne tylne, niezaokrąglone [a] oraz labializowane [p]. Dwa ostatnie typy wymowy charakterystyczne są dla najstarszego informatora, co zgodne by było z zakładanym przeze mnie powyżej rozwojem *[a] w PK.

Pod względem barwy *[a] gwara luzińska nawiązuje więc wyraźnie do PK i odcina się od CK. Choć obecnie różnica w wymowie *[a] pomiędzy tymi ugrupowaniami dialektalnymi wydaje się być w fazie zaniku, to i tak jest nadal obecna. Tendencja do ciemnej wymowy $a$ krótkiego w PK jest przy tym zjawiskiem stosunkowo świeżej daty, a jej wycofanie nie jest wynikiem kontaktów pomiędzy gwarami kaszubskimi, tylko wpływu ogólnej polszczyzny.

18 Lorentz dostrzega tu tylko drobną i ulotną różnicę pomiędzy ugrupowaniami dialektalnymi, choć pod względem wyszczególniania różnego rodzaju barw i odcieni samogłoskowych był bardzo pedantyczny, niekiedy nawet przesadnie, niepotrzebnie obciążając i nazbyt komplikując swoje opisy. U Z. Topolińskiej można mówić dopiero o zalążkach wymowy labializowanej. Na niektórych przynajmniej obszarach stan dzisiejszy byłby więc efektem dynamicznego rozwoju w ostatnich kilkudziesięciu latach.

19 Bardzo prawdopodobne, że jest to reakcja na przesuwanie się *[ə] w kierunku [æ] w tych gwarach. 


\subsection{Wymowa *[a:] (nie przed $[\mathrm{N}])$}

Jak wiadomo, wymowa *[a:] ulegała w ciągu ostatnich 100-150 lat dość dynamicznym zmianom, zarówno jeżeli chodzi o barwy, jak i ich zasięgi geograficzne (Siatkowski 1965; Topolińska 1960: 168-169; Rzetelska-Feleszko 2009a; Rzetelska-Feleszko 2009b) ${ }^{20}$. Obecnie - wskutek tendencji obserwowanych już dawniej (AJK 14: 45-48, mapa 651, mapa syntetyczna 1-2) - pod względem wymowy dawnego $a$ długiego obszar CK dzieli się na dwa wyraźne obszary. Gwary ZCK (łącznie ze S) mają tu [э̣] swobodnie wymieniające się na $[\varepsilon]$ (np. słowo trôwa 'trawa' u jednego i tego samego informatora może być wymówione zarówno jak ['trọvä], jak i ['trદvä]). Proporcje występowania tych wariantów są zależne zarówno od preferencji indywidualnych, jak i kontekstu, ale obie barwy występują u wszystkich i ogólnie wyraźnie częstsze jest [э̣]. Po miękkich i welarnych [э̣] podlegać może substytucji na [i]. Innych wariantów w zebranych i przebadanych materiałach nie stwierdziłem. Gwary WCK zachowują zazwyczaj wymowę labializowaną typu [e], czasa-

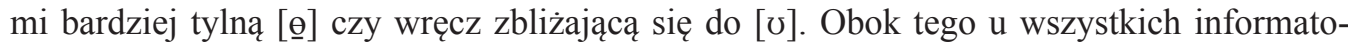
rów, a zwłaszcza młodszych, zaobserwować można kontynuanty bez labializacji, takie jak na zachodzie $([\stackrel{\jmath}{,} \varepsilon])$, występujące również tu w pełni wymiennie. Pomiędzy obu obszarami mamy wąski pas przejściowy, gdzie tylko starsi informatorzy zachowują fakultatywnie (rzadziej niż na wschodzie) wymowę labializowaną, a ponadto po wargowych i welarnych możliwa jest wymowa dyftongiczna [wọ]. U informatora z Bojana stwierdziłem wymowę [ө]. Jeżeli chodzi o gwary niewątpliwie PK, to w Wierzchucinie i Nadolu pod akcentem występuje [ө]. Również poza akcentem ta barwa jest możliwa, najczęściej mamy tu jednak do czynienia z delabializacją i wymową [ə̣]. W Chłapowie wymowa waha się pomiędzy [ө] a [ø], przy czym labializacja wariantów bardziej tylnych może być słaba. Tylko dla Jastarni charakterystyczna jest wymowa typu [0] (punktem ciężkości jest tu raczej [?] z wahaniami pod względem stopnia otwarcia w obie strony). Wymowa *[a:] w gwarze luzińskiej była dotąd opisywana sprzecznie, przy czym dotyczy to również opracowań sobie wspó1czesnych. Gotthelf Bronisch $(1896: 3,12,88)$ stwierdza tu dźwięk pośredni pomiędzy [0] i [o]. Zgodny jest tu K. Nitsch, który zauważa, że głoska ta sprawia wrażenie ciemniejszej od ogólnopolskiego $o$ (Nitsch 1903: 225). F. Lorentz natomiast przypisuje gwarze luzińskiej wymowę niską typu [p] (Lorentz 1927-1937: 304). P. Smoczyński stwierdza w Luzinie „utrzymanie się” wymowy „tylnej i niskiej” o (Smoczyński 1955: 81). Autorzy AJK notują głównie [0], ale marginalnie występować mają tu również inne barwy (AJK 14, 43-51, mapy 651-652, mapy syntetyczne 1-6). Z. Topolińska dostrzega natomiast w gwarze luzińskiej wyłącznie wymowę tylno-centralną, stosunkowo niską i zaokrągloną, czyli coś w rodzaju [o, @ ] (Topolińska 1967: 108-112, 113-114, 119; 1974: 96-100). W materiale przebadanym przeze mnie *[a:] to przeciętnie samogłoska tylna i średnia, wyższa od średniego otwartego [0] i niższa od średniego zamkniętego [o]. Również stopień zaokrąglenia jest pośredni pomiędzy typowym dla poziomu średniego otwartego i średniego zamkniętego. Realizacje skrajne zbliżają się pod obu względami z [0] z jednej strony i z [o] $\mathrm{z}$ drugiej. W precyzyjnej transkrypcji należałoby zapisać przeciętny wariant za pomocą

${ }^{20}$ Dla ilustracji warto tu przytoczyć fakt, iż w gwarach ZCK w pewnych kontekstach fonetycznych *[a:] przebyło drogę od pierwotnego tylnego, niskiego i labializowanego [p] do przedniego, wysokiego i nielabializowanego [i], czyli pomiędzy maksymalnie przeciwległymi punktami przestrzeni samogłoskowej. 
symbolu [?] . Najbliższy stwierdzonemu przeze mnie stanowi jest więc w zasadzie opis najstarszy, autorstwa G. Bronischa. F. Lorentz uogólnił być może błędnie fakultatywną i niezbyt częstą wymowę archaiczną, niewykluczone też, iż uległ tu swym założeniom teoretycznym (Siatkowski 1965: 412). P. Smoczyński i autorzy AJK byli być może w zakresie opisu barwy podstawowej mniej precyzyjni. Poza tym AJK z racji na obszerny korpus badawczy mógł zarejestrować rzadsze barwy oboczne, dzisiaj najprawdopodobniej już nieistniejące zupełnie. Jeżeli chodzi o opis Z. Topolińskiej, to mamy tu chyba do czynienia z błędną percepcją i jakąś autosugestią, zresztą w zakresie barwy *[a:] niejedyną w tekstach tej badaczki, por. (Jocz 2015b: 33). Stawia to pod znakiem zapytania wspomniane już powyżej ujęcie historycznojęzykowe Z. Topolińskiej, dopatrującej się w rozwoju *[a:] m.in. w gwarze luzińskiej jakichś szczególnych związków z PK i przyporządkowującej ją na tej podstawie do gwar PK.

Rozwój *[a:] izoluje więc gwarę luzińską łącznie z niewielkimi obszarami przyległymi od wszystkich sąsiednich gwar CK i PK. Mamy tu do czynienia z zachowaniem wymowy bardziej archaicznej i nieuczestniczeniem w innowacji polegającej na przesunięciu artykulacji *[a:] do przodu. Podobna do luzińskiej wymowa w innych, sąsiadujących czy niesąsiadujących z nią gwarach (zresztą nie należy tu tylko PK gwara Jastarni, ale również południowokaszubska zaborszczyzna) nie może być więc żadnym argumentem co do przynależności do ugrupowań dialektalnych. Podwyższenie kontynuantów *[a:] w kierunku [๑, ə] (i dalej w górę) było bez wątpienia cechą ogólnokaszubską (obecną do dziś również na Zaborach), poprzedzającą typowe dla części gwar przesunięcie artykulacji w przód (kontynuanty nietylne w tych gwarach są poziomu średniego, zazwyczaj średniego zamkniętego). Nie sposób tu więc dostrzegać jakiejkolwiek innowacji w zakresie rozwoju *[a:], łączącej gwarę luzińską tylko i wyłącznie z jakimkolwiek innym kaszubskim obszarem dialektalnym.

\subsection{Wymowa *[o]}

Wymowa przednia monoftongiczna (niezaokrąglona) po niemarginalnych ${ }^{21}$ zachowuje $^{2}$ się dziś w gwarze luzińskiej tylko jako fakultatywny relikt w pozycji wygłosowej, z wysokim prawdopodobieństwem jako zjawisko zmorfologizowane (ograniczone do końcówek). Jak już wspomniałem wyżej, ze współczesnej perspektywy jest to zjawisko nieistotne dla klasyfikacji gwar kaszubskich. Wszystkie bowiem pozostałe gwary znające przesunięcie *[o] do przodu również po niemarginalnych są obecnie wymarłe i mamy tu w zasadzie do czynienia z osobliwością typową dla całego interesującego nas obszaru i poza niego niewykraczającą.

Szersze rozważania rozpocznijmy od wariantów tylnych monoftongicznych i ich ewentualnych dalszych modyfikacji. Po niemarginalnych, gdzie poza określoną powyżej pozycją jest to jedyny sposób realizacji $*[0]$, jest to bez wątpienia wymowa wtórna, powstała pod wpływem sąsiednich gwar. Nie sposób jednak stwierdzić, czy któraś z nich odegrała tu większą rolę niż inne. Pierwotna wymowa luzińska była dość powszechnie przedrzeźniana i wyśmiewana (Treder 1999: 289-290, Topolińska 1967: 122), a inwazja barwy tylnej za-

${ }^{21}$ Tak określam wszystkie spółgłoski poza labialnymi i welarnymi, które z kolei określam mianem marginalnych. 
chodziła bez wątpienia zarówno z kierunku północnego, jak i południowego (Lorentz 1927-1937: 253). Wymowa tylna monoftongiczna występuje również po marginalnych. W ostatnim stuleciu doszło tu prawdopodobnie do pewnych przesunięć i zmian. Mogły być one częściowo uwarunkowane wpływem polszczyzny, choć w żadnym wypadku nie przypisywałbym jej tu roli motoru napędowego ${ }^{22}$. K. Nitsch dostrzega wyłącznie nieliczne i zleksykalizowane przypadki braku dyftongizacji po marginalnych (Nitsch 1903: 226, 229-231, 233; Nitsch 1907: 178). W materiale AJK oraz u P. Smoczyńskiego i Z. Topolińskiej wymowa monoftongiczna $\mathrm{w}$ tej pozycji jest natomiast całkowicie fakultatywna i ogólnie nierzadka (Smoczyński 1955: 80; Topolińska 1967: 108-112, AJK 14: mapa 658-660, mapy syntetyczne 8-9). Na obszarze CK *[0] wymawiane jest w zasadzie jako głoska klasy [॰], tożsama z ogólnopolskim o lub bardzo jemu bliska. W przypadku wyraźniejszej różnicy w stosunku do wymowy polskiej głównym czynnikiem jest wyraźne zaokrąglenie, któremu może towarzyszyć bardzo lekkie podwyższenie artykulacji. Realizacje wybitnie wyższe w rodzaju [o] zanotowałem absolutnie wyjątkowo. Ciemniejsza wymowa jest przy tym w pewnym stopniu uwarunkowana pozycyjnie, pojawia się bowiem zauważalnie częściej w sąsiedztwie spółgłosek wargowych. Realizacji o charakterze dyftongu opadającego typu [ou] w materiale CK nie stwierdziłem. Przejdźmy do gwar PK. Z. Topolińska (1969: 83) ogólnie zauważa, iż podstawowy wariant *[॰] jest węższy od ogólnopolskiego, wykazując tendencję do wymowy jako dyftong opadający. Jeżeli chodzi o stan współczesny, to w gwarze żarnowieckiej akcentowane *[0] wymawiane jest właściwie bez wyjątku jako przeciągły dyftong [рo] o wyraźnej (i wzrastającej w trakcie trwania) labializacji. W Chłapowie u informatora w wieku średnim najbardziej reprezentatywną wymową było [ơ, ơ], u informatora młodszego zaobserwowałem najczęściej wymowę tożsamą w zasadzie z ogólnopolską, choć pojawiają się tu również realizacje nieco wyższe i o silniejszej labializacji. W Jastarni zarówno u reprezentanta pokolenia starszego, jak i średniego zaobserwowałem wahania pomiędzy wymową tożsamą z ogólnopolską a nieco podwyższoną i bardziej labializowaną, czyli samogłoskę typu [?]. Ogólnie można więc stwierdzić, iż gwary PK wykazują wyraźną, choć na części obszaru najprawdopodobniej wycofującą się tendencję do zwężenia (z ewentualną dyftongizacją) kontynuantów *[o]. Gwary CK znają natomiast co prawda wymowę nieco ciemniejszą od ogólnopolskiej, nie obserwujemy tu jednak tak wyraźnego zwężenia, nie mówiąc już o dyftongizacji. W gwarze luzińskiej tylne monoftongiczne kontynuanty *[o] są tożsame z kontynuantami *[a:]. Najbardziej typową wymową jest więc głoska pośrednia zarówno pod względem poziomu, jak i zaokrąglenia pomiędzy [o] i [o]. Możliwe są przy tym realizacje bliskie [o] z jednej strony i [o] $\mathrm{z}$ drugiej.

PK jest pod względem wymowy kontynuantów *[o] (w zakresie omawianym w powyższym akapicie) niejednolita, a różnica pomiędzy CK a częścią gwar PK jest dziś niezbyt uderzająca i ma charakter zanikowej. Niemniej jednak również w tym przypadku stwierdzić możemy wyraźne nawiązanie gwary luzińskiej do północnej kaszubszczyzny, polega-

22 Być może poza pojedynczymi gwarami dyftongiczne kontynuanty *[॰] zawsze były i nadal są (fakultatywnymi) alofonami */o/. Nie mielibyśmy tu więc w żadnym wypadku wpływu polszczyzny o charakterze fonologicznym, a ewentualnie pewien wpływ na preferencje alofoniczne lub wsparcie przez polszczyznę rodzimych tendencji w tym zakresie. 
jące na wspólnej, innowacyjnej tendencji do zwężenia *[0]. Tendencja ta była zapewne wywołana skłonnością do tylnej i zaokrąglonej wymowy *[a] na tym obszarze.

Przejdźmy do wymowy dyftongicznej po marginalnych. W większości gwar kaszubskich *[0] w tej pozycji wymawiane jest jako dyftong rosnący typu [GV], gdzie [G] to glajd tylny zaokrąglony, a [V] to zazwyczaj samogłoska przednia lub centralna, rzadziej tylna. Segment [V] w przypadku artykulacji przedniej jest zwykle niezaokrąglony, w przypadku tylnej zaokrąglony, jeżeli zaś chodzi o realizacje centralne, to rzecz ma się różnie, por. (AJK 14: 76-77, mapa 660). Jak zaznaczyłem powyżej, tego rodzaju wymowa dyftongiczna wszędzie jest fakultatywna, konkurując $\mathrm{z}$ wymową monoftongiczną we wszystkich morfemach i u wszystkich informatorów. W gwarach CK najbardziej typową wymową jest [wع], nierzadkie jest również [wọ]. Brak tu ścisłej alofonii, można jednak zaobserwować pewne skłonności (np. [wọ] jest dość rzadkie w wygłosie, a przed palatalnymi częstsze niż w innych pozycjach). Oprócz tego istnieją jeszcze rozmaite warianty poboczne, które są jednak wyraźnie rzadsze niż wymienione. W gwarze żarnowieckiej stwierdziłem dwa podstawowe warianty: starszy [03, oఠ] i nowszy $[w \varepsilon]$. Poza akcentem (w wygłosie) początkowa i końcowa faza dyftongu pierwszego typu mogą być sobie wyraźnie bliższe. W Chłapowie u młodszej informatorki zanotowałem [wع] obok rzadszego [w९̣]. U informatora W wieku średnim natomiast wystąpiło głównie coś w rodzaju [o9] obok [03]. W Jastarni u obu informatorów stwierdziłem głównie coś w rodzaju [w९] lub [ひ९]. U informatora $\mathrm{w}$ wieku średnim faza końcowa bliższa jest czasem [3], zwłaszcza poza akcentem, a u informatora $\mathrm{w}$ wieku starszym pojawia się w tej pozycji labializowana wymowa centralna. Oczywiście ze względu na stosunkowo szczupły materiał i niewielką liczbę informatorów nie należy absolutyzować sformułowanych spostrzeżeń co do wymowy PK. Można tu jednak chyba zauważyć pewne ogólne skłonności. Segment niezgłoskotwórczy ma mianowicie tendencję do wymowy wyraźnie mniej peryferyjnej od [w]. Segment zgłoskotwórczy wykazuje natomiast skłonność do wymowy centralnej i na znacznej części obszaru średniej zamkniętej. Jednocześnie u młodszych informatorów można zauważyć pewną tendencję do silniejszej separacji początkowej i końcowej fazy dyftongu w obu osiach. Brzmienie dyftongicznego kontynuantu *[0] po marginalnych w gwarze luzińskiej już od samych początków jej opisu było przedmiotem dyskusji naukowej (Nitsch 1903: 230-231). Sprzeczności pomiędzy istniejącymi opisami (Bronisch 1896: 87; Nitsch 1903: 230-231; Lorentz 1927-1937: 253, 261-262; Smoczyński 1955: 80; AJK 14: mapa 658-660, mapy syntetyczne 8-9; Topolińska 1967: 108-112) nie sposób objaśnić w kategoriach rozwoju gwary. Jeżeli wzięlibyśmy wszystkie dotychczasowe opracowania za dobrą monetę, to musielibyśmy przyjąć w ciągu ostatnich stu lat sześcioelementowy łańcuch procesów fonetycznych z dwukrotnym powtórzeniem identycznej sekwencji zmian, co jest mało prawdopodobne (Jocz 2016). W przebadanym przeze mnie materiale jedyną wymową pod akcentem jest [w९] ([९] jest przeciętnie nieco bardziej przednie niż centralne, poza tym pod wpływem sąsiedztwa fonetycznego mogą pojawiać się wymowy zarówno bardziej przednie, jak i bardziej tylne), poza akcentem w wygłosie [wê, wạ]. Segment niezgłoskotwórczy jest zawsze peryferyjny i wyraźnie artykułowany. Element zgłoskotwórczy to - poza jedyną, nacechowaną pozycją - samogłoska poziomu średniego wysokiego. Separacja pomiędzy obiema fazami dyftongu jest duża, brak tu też artykulacji monoftongicznych centralnych.

W kwestii dyftongicznej wymowy *[0] po marginalnych w gwarze luzińskiej ciężko dopatrywać się jakichkolwiek wyraźnych nawiązań do PK czy CK. Pod względem seg- 
mentu niezgłoskotwórczego interesująca nas gwara zgodna jest z CK. Jeżeli zaś chodzi o segment zgłoskotwórczy (głównie jego poziom), to gwara luzińska odcina się dość wyraźnie od CK, gdzie podstawowym wariantem jest [wع], a [w९̣] tylko wariantem pobocznym. W tej kwestii możemy bardzo ostrożnie mówić o pewnym nawiązaniu do części gwar PK. Być może istnieje też jakiś związek pomiędzy średnią zamkniętą wymową końcowego segmentu dyftongu a ogólnym podniesieniem * $[\varepsilon]$, będącym nawiązaniem do PK. Brak w interesującej nas gwarze wymów o małej separacji początkowej i końcowej fazy dyftongu czy wręcz centralnych monoftongicznych, mniej lub bardziej charakterystycznych dla gwar PK. Dodać tu należy, iż stabilność (w sensie braku w zasadzie zauważalnych swobodnych wahań) wymowy dyftongicznej *[o] po marginalnych odróżnia gwarę luzińską od wszystkich znanych mi sąsiednich gwar kaszubskich. Ogólnie dla celów niniejszego artykułu kwestię wymowy *[o] w rozpatrywanej tu pozycji uznać należy za mało użyteczną.

\subsection{Wymowa *[o:]}

Brzmieniem pierwotnym *[o:] było we wszystkich gwarach kaszubskich niewątpliwie średnie zamknięte [o]. Już F. Lorentz (1927-1937: 285-286), konstatując utrzymanie takiej wymowy w większości gwar, dostrzega tendencję do artykulacji bliskiej $u$ w południowej kaszubszczyźnie oraz wymowy jako dyftong opadający typu [ow] w części gwar PK (a dokładniej w słowińskich).

Obecnie w gwarach CK *[o:] wymawiane jest jak luźne [u], całkowicie tożsame z ogólnopolskim $u$. Poświadczenia wymowy nieco szerszej czy scentralizowanej są bardzo rzadkie i w większości przypadków dają się wytłumaczyć jako wtórne zjawisko alofoniczne czy spontaniczne niedociągnięcia artykulacyjne. Jakiegokolwiek systemowego charakteru takich izolowanych wymówień stwierdzić nie sposób. Taka wymowa jest w gwarach CK bez wątpienia zjawiskiem stosunkowo nowym. Nie odnajdujemy jej w cytowanym przed chwilą opracowaniu F. Lorentza. Z. Topolińska (1967: 120) zna taką wymowę tylko jako fakultatywną na południowozachodniej części obszaru CK. Nie stwierdziłem w gwarach CK wymowy w formie dyftongu opadającego. Jeżeli chodzi o wymowę PK, to oprócz wymowy typu [o] badaczka stwierdza ogólnie niezbyt częstą dyftongizację na [ow]. W gwarze żarnowieckiej pod akcentem występuje wyłącznie przeciągły dyftong (dyftongoid) w rodzaju [oo]. W Jastarni nie zanotowałem żadnego innego wariantu niż [عw]. W Chłapowie u informatorki młodszej stwierdziłem głównie [u], o wiele rzadziej coś w rodzaju [o]. U informatora $\mathrm{w}$ wieku średnim zanotowałem barwy pośrednie pomiędzy [o, ư] i $[\mho]$. W przebadanym przeze mnie materiale luzińskim *[o:] wymawiane jest przeciętnie jako głoska wahająca się pomiędzy stosunkowo wyraźnie opuszczonym [ư] i [o] ze skłonnością do artykulacji skrajnie tylnej. Rzadziej, choć regularnie występują również warianty bardziej otwarte, które można zdefiniować jako niezbyt silnie labializowane [o] (poza akcentem możliwa jest nawet wymowa [o]). Poza tym zanotowałem także stosunkowo rzadką wymowę dyftongiczną typu [oư].

Gwary luzińskiej nie objęła więc CK innowacja ${ }^{23}$ polegająca na zwężeniu *[o:] do barwy [u] (choć nie mogę z pewnością wykluczyć, czy taka wymowa nie występuje u młod-

${ }^{23}$ Niewykluczone, że w CK mamy do czynienia z rozpowszechnieniem się tendencji pierwotnie południowokaszubskiej. Można również przypuszczać, iż jakąś rolę odegrał tu wpływ ogólnej polszczyzny. 
szych użytkowników gwary). Dotarła tu natomiast PK kaszubska tendencja do wymowy dyftongicznej, która jednak w przebadanym przeze mnie materiale pojawia się dość rzadko. Ogólnie wymowa jest tu archaiczna, podobnie jak w gwarach PK.

\subsection{Wymowa *[u]}

Najbardziej pierwotną dla całego obszaru kaszubskiego wymową *[u] było bez wątpienia tylne i zamknięte [u]. We większości gwar doszło jednak na późniejszych etapach rozwoju do mniej lub bardziej fakultatywnego przesunięcia artykulacji w przód z ewentualną pełną delabializacją po niemarginalnych i dyftongizacją po marginalnych. Zmiany te wraz ze zróżnicowaniem gwarowym znane są już od najstarszych naukowych opisów kaszubszczyzny, zarówno z gwar północnych, jak i centralnych i południowych (Bronisch 1896: 14-15, 88; Nitsch 1903: 114-115, 122, 142-143, 162).

$\mathrm{Na}$ wschodniej części obszaru CK stwierdziłem zarówno po marginalnych, jak i po niemarginalnych wymowę monoftongiczną. Najbardziej typowe są realizacje centralne $[\mathfrak{u}]$, ale możliwe są również przednie jak [Y] i tylne typu [u, ụ]. Wymowa dyftongiczna występuje w zasadzie tylko w nagłosie i po samogłoskach. W gwarach ZCK (łącznie ze S) po marginalnych najbardziej typową realizacją jest dyftong [wọ], końcowa faza dyftongu może jednak zachowywać labializację, co najczęściej daje wymowę typu [wu]. Obok realizacji dyftongicznych fakultatywnie występują również monoftongi wysokie labializowane tylne typu $[\mathrm{u}]$ i centralne typu $[\mathrm{u}]$. Po niemarginalnych wymowa monoftongiczna zaokrąglona ([u, $\mathrm{u}, \mathrm{y}])$ konkuruje $\mathrm{z}$ niezaokrągloną ([э̣, i]). Przejdźmy do PK. W gwarze żarnowieckiej zanotowałem głównie wymowę centralną ([u]), przednio-centralną ([ษ, y]) i przednią $([\mathrm{y}])$, tylną $([\mathrm{u}])$ natomiast stwierdziłem tylko po /w/. W Chłapowie u informatora $\mathrm{w}$ wieku średnim zanotowałem barwy od $[\mathrm{u}]$ przez $[\mathrm{u}]$ do $[\mathrm{y}]$. U informatora młodszego stwierdziłem wymowę typu [э, ९ฺ, I], będącą bez wątpienia wynikiem delabializacji wariantów centralnych i przednich zaokrąglonych. W Jastarni u obu informatorów wystąpiły wahania pomiędzy $[\mathrm{u}]$ a $[\mathrm{u}]$. Choć wymowa w poszczególnych gwarach i u poszczególnych informatorów jest więc różna, na obszarze gwar CK i PK stwierdzić możemy ogólnie wyraźnie zaznaczoną obecność wymów przedniejszych niż tylna. W zależności od gwary i od pozycji wymowa nietylna może być absolutnie dominująca. W przebadanym przeze mnie materiale luzińskim we wszystkich pozycjach występuje wyłącznie barwa tylna typu [u], co pokrywa się z opisem F. Lorentza (1927-1937: 316-317, 323-324, 327). Co ciekawe, późniejsze opracowania poświadczają pewną tendencję do wymowy bardziej przedniej również w interesującej nas gwarze (Nitsch 1903: 226, 234; Nitsch 1907: 178; AJK 14, 112-116, mapy 671-672, mapy syntetyczne 15-16; Topolińska 1967: 108-112, 120), przynajmniej w pewnych specyficznych kontekstach. Już P. Smoczyński stwierdził jednak, iż tendencja taka przestała się szerzyć, widząc tu wewnętrzną tendencję gwary do „odpalatalizowania artykulacji wszelkich w ogóle głosek" (Smoczyński 1955: 81).

Pod względem wymowy *[u] gwara luzińska nie łączy się więc z żadnym z sąsiednich ugrupowań dialektalnych, wyraźnie odróżniając się zarówno od gwar CK, jak i PK. Również z punktu widzenia zarodkowej tendencji do wymowy bardziej przedniej, zaobserwowanej w opracowaniach sprzed kilkudziesięciu lat, nie można dopatrywać się silniejszych związków z żadnym z sąsiednich dialektów. 


\subsection{Wymowa *[ə]}

Pierwotna wymowa szwa kaszubskiego w przeważającej większości gwar to zapewne głoska centralna i średnia, nielabializowana typu [ə]. W gwarach zaborskich rozwój *[ə] poszedł głównie w kierunku przesunięcia artykulacji w tył i labializacji, choć na części obszaru możliwe jest zachowanie wymowy bardzo archaicznej typu [ơ, ə઼]. Pozostałe gwary kaszubskie objęła natomiast tendencja do dalszego obniżania wymowy wraz z przesunięciem w przód lub tył. W następnej kolejności powstała tu możliwość fakultatywnej identyfikacji $\mathrm{z} *[\varepsilon]$.

Na obszarze CK absolutnie dominującą wymową jest głoska niższa od poziomu średniego otwartego, tylna lub tylno-centralna i nielabializowana typu $[\stackrel{\wedge}{\mathrm{i}}]$. W gwarach ZCK jest to przy tym jedyny sposób wymowy (różny od *[ع]), przy czym to właśnie tutaj pojawiają się barwy wybitnie tylne. Na wschodzie oprócz takiej wymowy (przeciętnie nieco mniej ekstremalnie tylnej niż na zachodzie) bardzo rzadko pojawia się również samogłoska tego samego poziomu, ale szeregu przedniego, nieco scentralizowana, którą możemy zapisać jako [æ]. Wszędzie możliwa jest również identyfikacja $\mathrm{z} *[\varepsilon]$, czyli wymowa typu $[\varepsilon$, $\varepsilon]$. PK jest obszarem wymowy zdecydowanie przedniej. W gwarze żarnowieckiej zakres wariantów wyznaczają punkty [æ, a, æ, a] (przy czym w przypadku [æ, a] chodzi o bardzo lekkie cofnięcie), innych fakultatywnych wariantów nie stwierdziłem tu w ogóle. W Chłapowie $\mathrm{u}$ informatora $\mathrm{w}$ średnim wieku notowałem wahania pomiędzy [æ] a [?] $\mathrm{z}$ fakultatywną wymową jako $[\varepsilon, \varepsilon]$ (odpowiadającą wymowie ogólnopolskiego $e$ ), informatorka młodsza ma już tylko $[\varepsilon, \underline{\varepsilon}]$. W Jastarni u osoby starszej zanotowałem [æ, æ, ș] obok $[\varepsilon, \underline{\varepsilon}]$. Informator średni wymawia głównie [a] , często o dość silnym cofnięciu, czasami niewiele różniące się już od jego wymowy *[a]. Oprócz tego pojawia się u niego również wymowa $[\varepsilon, \underline{\varepsilon}]$. Na podstawie starszej literatury stwierdzić można, iż tendencja do opuszczania *[ə] i przesuwania artykulacji w przód lub tył jest przynajmniej na części obszaru CK i PK dość świeżej daty, por. np. (Lorentz 1913: 158-184; 1927-1937: 221-222; Topolińska 1969: 68-74, 83) dla gwary żarnowieckiej. K. Nitsch opisywał luzińskie *[ə] jako najbardziej tylną samogłoskę, stwierdzając jej „niewyraźne umiejscowienie”, wywołujące „wrażenie akustyczne [...] dość zmienne" i konstatując, że dla niewprawnego ucha brzmieć ona ma jak samogłoska klasy a (Nitsch 1903: 224-225). F. Lorentz (1927-1937: 60, 221) dla niemal całej kaszubszczyzny przyjmuje brzmienie typu [ə], sugerując drobne różnice gwarowe, których jednak dokładniej nie opisuje. Z. Topolińska definiuje *[ə] w ogólnym opisie jako samogłoskę niską i przednią, zauważając jednak również wymowę wyższą m.in. w miejscowościach należących do gwary luzińskiej. Badaczka przytacza tu przy tym charakterystykę opozycji pomiędzy *[ə] i $*[\varepsilon]$, podaną jej przez dwoje luzinian. Jedna z osób zwraca uwagę na krótkość i zredukowany charakter *[ə], druga zaś na szerszą wymowę *[ə] (Topolińska: 113, 120). W przebadanym przeze mnie materiale przeciętną realizacją *[ə] jest głoska bardzo bliska polskiemu e lub wręcz z nim tożsama, czyli samogłoska średnia otwarta, i scentralizowana w stosunku do szeregu przedniego, którą możemy oznaczyć jako [ㅌ, ș]. Nierzadkie, zwłaszcza indywidualnie, są realizacje bardziej otwarte typu $[\mathfrak{x}, \mathfrak{p}]$. Wymowa bardziej tylna $\left[\underline{3}, \Lambda_{\uparrow}\right]$ występuje w zasadzie tylko w (obustronnym) sąsiedztwie spółgłosek wargowych.

Jak widzimy, w kwestii wymowy *[ə] nie zawsze mamy do czynienia z absolutnie ostrymi różnicami pomiędzy poszczególnymi gwarami i ugrupowaniami dialektalnymi. 
Różnice te są jednak i tak bardzo wyraźne i - co szczególnie ważne - w pewnym przynajmniej zakresie stosunkowo nowe. Z punktu widzenia tych tendencji stwierdzić należy w danym zakresie nawiązanie gwary luzińskiej do PK i jej odrębność od gwar CK, a zwłaszcza od sąsiadujących z nią bezpośrednio gwar ZCK. Mamy tu przy tym do czynienia z zasadniczym uczestniczeniem gwary luzińskiej w innowacji PK i zasadniczym nieuczestniczeniem $\mathrm{w}$ innowacji $\mathrm{CK}$.

\subsection{Wymowa *[ã] wraz z [aN] i *[õ $]$}

O dynamice w zakresie wymowy pierwotnych samogłosek nosowych, zarówno pod względem barwy ustnej, jak i charakteru nosowości, dowiadujemy się już z opisu Aleksandra Hilferdinga (Гильфердинг 1862: 84-85) czy Leona Biskupskiego (Biskupski 1883: 6, 12-17, 19-20, 38-39, 50-56). Ogromne zróżnicowanie pomiędzy poszczególnymi gwarami, ale również rozchwianie w obrębie jednej i tej samej gwary w połowie 20 wieku poświadcza monograficzne opracowanie autorstwa Aliny Ściebory (Ściebora 1973). O czasu tego opisu doszło do kolejnych, bardzo znacznych zmian w zakresie wymowy nosówek, które tylko dla niektórych obszarów gwarowych zostały dotychczas opisane w wyczerpujący sposób.

Na obszarze CK rozwój szedł w kierunku denazalizacji i zmiany barwy ustnej pierwotnych samogłosek nosowych. Centrum tego procesu była gwara sierakowsko-gowidlińska (czy ogólniej ZCK). Nosowość zachowana jest tu tylko przed [k, g] jako [n] (np. rãka ['räykä] 'ręka', bąk [bunk] 'bąk'), a w przypadku *[õ] jeszcze w wygłosie (np. $s q$ [sum] 'są'). W gwarze kartusko-goręczyńskiej (ogólniej w WCK) odnosowienie również występuje (i postępuje), jednak tu zachowuje się ono fakultatywnie również poza wymienionymi powyżej pozycjami w formie homoorganicznej spółgłoski nosowej lub glajdu typu [ũ, õ] czasem o bardzo słabej nosowości (np. wiãcy ['vjotsi, 'vjontsi, 'vjəũtsi] 'więcej'). Na południu całego obszaru CK częsta czy wręcz dominująca jest denazalizacja wygłosowego *[õ] (np. $s a$ [su] 'są'), wymowa taka pojawiać się może zresztą również bardziej na północ. Taki zakres denazalizacji na obszarze ZCK jest zjawiskiem stosunkowo nowym. Wspomnieć tu wystarczy, że A. Ściebora charakteryzuje poświadczenia denazalizacji (w stosunku do form z zachowaną nosowością synchroniczną) na tym terenie jako „stosunkowo nieliczne" i zastanawia się, czy mamy tu do czynienia ze zjawiskiem nowym, czy reliktami zjawiska zanikającego (skłania się ona co prawda ostatecznie ku pierwszej interpretacji, ale już sama możliwość postawienia hipotezy odmiennej jest bardzo wymowna). *[õ] przybiera bezwyjątkowo barwę [u]. Wymowa ustna *[ã] waha się - nie tylko w obrębie poszczególnych gwar, ale również w pojedynczych idiolektach - pomiędzy [a, $\mathrm{p}$, o $]^{24}$, przy czym przy denazalizacji (fonetycznej) barwy [p, o] są w śródgłosie niemal obligatoryjne (np. zãbë ['zobs, 'zpbe] 'zęby' obok rãka ['räyka, 'ronka] 'ręka') W wygłosie wymiany barwy są całkowicie swobodne (np. robiã ['robja, 'robjo, 'robjp] 'robię'). Identycznym wahaniom podlega *[a] przed [N] (np. tam [täm, tom, tom] 'tam'). Odcinają się tu peryferie północne. Już w Mirachowie (przynajmniej u pokolenia starszego) obok denazalizacji w śródgłosie na opisanych powyżej zasadach często występuje zachowanie nosowości w formie glajdu lub homoorganicznej spółgłoski nosowej lub (możliwa jest też kombi-

${ }^{24}$ Barwa [p] jest typowa dla gwar ZCK. 
nacja obu elementów i wymowa [VũN]). W Strzepczu natomiast denazalizacji w śródgłosie nie zaobserwowałem ani razu. U wszystkich informatorów wystąpiło tu rozszczepienie na samogłoskę i homoorganiczną spółgłoskę nosową (przed zwartymi) lub glajd (przed szczelinowymi). Brak tu poza tym (również w wygłosie) niemal zupełnie zmian barwy *[ã], w przeważającej większości przypadków stwierdziłem [ä] i tylko absolutnie wyjątkowo [o]. Gwara strzepska nie uczestniczyła więc w skądinąd intensywnej i ekspansywnej innowacji ZCK. Osobno omówić należy rozwój końcówki narzędnika *-em. W gwarach CK obserwowałem tu zasadniczo wymowę typu [cm]. Tylko w okolicach Gowidlina i w Strzepczu zanotowałem dość rzadkie wymowy typu [o, o, a] (dzeckã ['dzctskp] 'dzieckiem', kòniã ['kwعnä] 'koniem'). Brak wtórnej nosówki w słowie tam. Materiał PK, jakim dysponuję, jest w kwestii nosówek w pewnym zakresie ograniczony, pozwala jednak na uchwycenie zasadniczych tendencji. W gwarze żarnowieckiej śródgłosowe *[ã] po twardych wymawiane jest jako połączenie [э๋] z homoorganiczną spółgłoską nosową przed zwartymi lub glajdem typu [ũ] przed szczelinowymi (np. zãbë ['zọmbə઼] 'zęby', rãce ['rọntsə̣] 'ręce', dãbë ['dọmbə̣] 'dęby'). Po miękkich wymowa zbliża się do [i] lub z nim utożsamia. Śródgłosowe *[õ] wystąpiło jako samogłoska klasy [o] z homoorganiczną spółgłoską nosową. W Chłapowie wymowa jest ogólnie tożsama z tą w gwarze żarnowieckiej (np. piãc [piiĩnts] 'pięć', dzewiãc ['dzọvjjọnts] 'dziewięć', jãzëk ['jọũzọk] 'język', zãbë

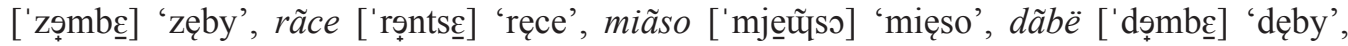
miesac ['mjêsõnts] 'miesiąc'). Słowo tam przyjmuje tu wymowę [ț̣m]. W Jastarni w przypadku *[ã] stwierdziłem najczęściej wymowę półniską, ale nierzadkie okazały się również realizacje niższe z jednej strony i wyższe z drugiej. Z resztą obszaru PK łączy Jastarnię tendencja do wymowy przedniej. Rozszczepienie zazwyczaj, aczkolwiek nie zawsze połączone jest z asymilacją powstałej spółgłoski nosowej do następującej spółgłoski (np. piãc [p6ints] 'pięć', dziesięć ['dzễsọnts] 'dziesięć', jãzëk ['jäũzək] 'język', zãbë ['zẹmbə̣] 'zęby', ręce ['rẹntsə̣] 'ręce', miãso ['mjaũuso] 'mięso', dzesãc ['dzọsınts] 'dziesięć', jãzëk ['jæũzọk] 'język', zãbë ['zæmbơ] 'zęby', rãce ['rơỡtsọ] 'ręce', miãso ['mjẹmso] 'mięso',

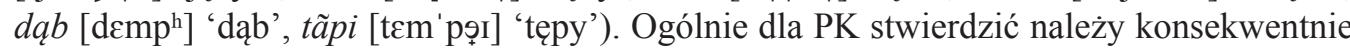
chyba przeprowadzoną konsonantyzację nosowości. Kilkadziesiąt lat temu proces ten był niewątpliwie mniej zaawansowany, już wtedy jednak gwary PK były ogniskiem silnej tendencji do rozszczepienia samogłosek nosowych (Ściebora 1973: 15, 165-167). Dawna nosówka krótka charakteryzuje się w gwarach PK silniej lub słabiej zrealizowaną tendencję do przesuwania artykulacji w górę i w przód. Jeżeli zaś chodzi o dawną nosówkę długą, to szczupłość materiału uniemożliwia sformułowanie zdecydowanych wniosków. Niemniej jednak możemy tu założyć brak zdecydowanej tendencji do wznoszenia w kierunku [u] i skłonność do stabilizacji wymowy na poziomie średnim (abstrahuję tu od specyficznych zjawisk w Jastarni).

W gwarze luzińskiej *[ã] wykazuje praktycznie wyłącznie barwę [ạ], tożsamą z miejscowym kontynuantem *[a]. Wyjątki są nieliczne. W przypadku barwy $[\varepsilon]$ kontekst lub semantyka konkretnego słowa zawsze właściwie sugeruje, że mamy do czynienia z użyciem formy polskiej. Wymowa typu [0] wystąpiła tak rzadko, że nie jest pewne, czy nie mamy w jej przypadku do czynienia z lapsusem. Innych barw nie zarejestrowałem. Co ciekawe, niektóre starsze opracowania poświadczają dla gwary luzińskiej PK tendencję do przesunięcia wymowy *[ã] w przód i ewentualnie w górę (Nitsch 1903: 226; AJK 13: 169-197, mapy 624-634; Topolińska 1967: 108-112, 113, 118). P. Smoczyński stwierdza 
wyłącznie relikty wymowy pośredniej pomiędzy $a$ i $e$ oraz wymowę $e$, ale tylko u najstarszych informatorów. Młodsi wykazują natomiast konsekwentną wymowę jako a (Smoczyński 1955: 80-81). Można tu więc mówić o wycofaniu się w gwarze luzińskiej zarodkowej tendencji mającej źródło w gwarach niewątpliwie PK. Nie sposób tu jednak mówić o nawiązaniu do sąsiadujących gwar CK, wymowa typu $a$ jest bowiem archaizmem, w interesującej gwarze obecnym „od zawsze” i „zawsze” w niej dominującym. Wycofanie się barw bardziej przednich i wyższych mogło być wynikiem tendencji do usuwania obocznych form fonetycznych przy pewnej skłonności do ustalania się brzmień odmiennych od ogólnopolskich, por. (Ściebora 1973: 184-185, 187). W zakresie barwy *[ã] gwara luzińska nie wzięła więc ostatecznie udziału (łącznie z niewątpliwie CK gwarą S) ani w najnowszych innowacjach CK, ani PK.

Barwa *[õ] w przebadanym przeze mnie materiale luzińskim obejmuje bez widocznych reguł alofonicznych pełen zakres od [0] ([0]), poprzez [o], aż do [u] ([ư]). Najbardziej typowa jest przy tym głoska typu [o]. Znaczna część dotychczasowych opisów prezentuje taką właśnie barwę jako jedyną, choć mniej lub bardziej eksplicytnie dokumentowana tu jest również pewna skłonność do wymowy wysokiej typu [u, ư] (Nitsch 1903: 223; Lorentz 1927-1937: 362; Topolińska 1967: 108-112, 113, 118-119). Materiał AJK poświadcza natomiast wszystkie barwy z zakresu od [0] do [u] (AJK 13: 169-197, mapy 624-634). Podobnie A. Ściebora, która pomimo zróżnicowania indywidualnego ogólnie stwierdza w wymowie pokolenia młodszego wyraźnie zwiększanie się częstotliwości występowania barwy [0] (Ściebora 1973: 143-147, 177-178 mapy 5-6, 25-36). Zakładając, iż punktem wyjścia na całym obszarze kaszubskim była barwa typu [0], stwierdzić by można nieuczestniczenie gwary luzińskiej w innowacji CK, polegającej na konsekwentnym wzniesieniu barwy *[õ] do poziomu $[\mathrm{u}]$ oraz częściowe zachowanie wymowy bardziej archaicznej, typowej w pewnym przynajmniej zakresie również dla obszaru PK. Historia rozwoju barwy wydaje się tu jednak w świetle dotychczasowej literatury dość skomplikowana i nie sposób tu chyba mówić o jednoznacznych związkach czy różnicach.

Alina Ściebora zwraca uwagę na dobre zachowanie nosowości synchronicznej na obszarze obejmującym m.in. gwarę luzińską. Podawane przez nią liczby (przy pewnym zróżnicowaniu w zależności od pozycji, wieku, indywidualnych preferencji informatorów itp.) sięgają np. dla kontynuantów dawnej nosówki krótkiej w śródgłosie ogólnie ok. 70\%-90\% całkowitej liczby obserwacji (Ściebora 1973: 15-60, 99-102). Dzisiejsze stosunki są diametralnie odmienne. Przed zwartymi w przypadku *[ã] w przeważającej większości realizacji mamy do czynienia z rozszczepieniem z asymilacją do następującej spółgłoski z pełnym odnosowieniem kontynuantu samogłoskowego (np. dãbë ['dạmbê]], rãce ['rạntsọ] 'ręce', rãka ['rạ̣kạ] 'ręka'). Rzadziej, ale nadal dość często nosowość samogłoski zachowuje się częściowo (np. piãc [pijaạ̃nts] 'pięć' czy dãbë ['dạũ̃mbə]). Rzadko występuje wymowa dyftongiczna (np. zãbë ['zạũ bə] 'zęby') a absolutnie wyjątkowo rozszczepienie bez asymilacji (piãc [pijậts] 'pięć'). Przed /1/ wymowa dyftongiczna konkuruje z odnosowieniem (np. wzãlë ['vzạũulễ] obok przëjãlë [pș̣̣'jạlọ] 'przyjęli'). Przed szczelinowymi zanotowałem niemal zawsze wymowę dyftongiczną (np. jãzëk ['jạũyộ] 'język'), bardzo rzadko rozszczepienie z asymilacją lub bez niej (miãso ['mijantso] 'mięso', jãzëk ['jạ̣zə̣̂] 'język'). W wygłosie (gdzie należy również *-em) najczęstsza denazalizacja (np. rzekã ['zọkạ] 'powiem') konkuruje z rozszczepieniem (np. rzekã ['zọkạ̃m] 'powiem') i wymową dyftongiczną czy o częściowej nosowości (np. chcã [xtsạũ] 'chcę' czy widzã ['vijidzạ̃a]] 
'widzę'). Jeżeli chodzi o śródgłosowe *[õ] przed zwartymi, to zaobserwowałem wyłącznie rozszczepienie $\mathrm{z}$ asymilacją, choć nosowość kontynuantu samogłoskowego często zachowuje się tu w pełni (np. miesąc [mjjọsõnts] 'miesiąc', wząc [vzõnts] 'wziąć', skąd [skõnt] 'skąd'), choć niemal równie często ją traci (np. piąti ['phjunti] 'piąty', piątk [pjọntk], stąd$k a$ [stưntka] 'stąd'). Przed szczelinowymi występuje wymowa dyftongiczna z zachowaniem nosowości kontynuantu samogłoskowego (np. gałąów ['gạ.õũzọf] 'gałęzi') lub bez niego (np. sąsadzë ['sôũsạdzə̦] 'sąsiedzi'). W wygłosie dominuje wymowa rozszczepiona (np. żódna ['zodnũm] 'żadną', ze mna ['zọmnưm] 'ze mną', sa [sõm] 'są') obok wymowy dyftongicznej (np. kradna ['krạdnũũ] 'kradną'). Rzadka jest denazalizacja (np. cała ['tsạwọ] 'całą'), a absolutnie wyjątkowa nosowość synchroniczna (nowa ['nọvõ] 'nową'). Mamy tu więc przy zachowaniu nosowości całkowite niemal przejście na wymowę niesynchroniczną, z pełną praktycznie konsonantyzacją nosowości przed zwartymi.

Gwara luzińska (łącznie z gwarą S) w pełni uczestniczyła w PK tendencji do konsonantyzacji nosowości w śródgłosie i nie uczestniczyła w CK tendencji do odnosowienia samogłosek nosowych w tej pozycji. Dodać tu należy, że w przeciwieństwie do gwary S stwierdziłem tu takie zjawiska jak rozszczepienie bez asymilacji (czyli wymowę [y] niezależnie od miejsca artykulacji następującej spółgłoski), konsonantyzację przed szczelinowymi, czy rozszczepienie z konsonantyzacją wygłosowego *[ã], znane współczesnym gwarom PK a zupełnie nieznane na obszarze CK.

Oczywiście w pewnym zakresie w rozwoju tendencji PK, która objęła ostatecznie gwarę luzińską, rolę mógł odegrać wpływ ogólnej polszczyzny, którego bym jednak nie przeceniał. Pewne bowiem zjawiska (jak wydzielenie się [m] u kontynuantu *[ã] w wygłosie) jest jej całkowicie obce, co sugeruje, że w dużej mierze przyjmować tu należy rodzimy rozwój kaszubski, rozprzestrzeniający się z jednych gwar do innych.

\subsection{Redukcja samogłosek nieakcentowanych}

Pojęcie redukcji samogłoskowej obejmuje zjawiska o charakterze zarówno fonologicznym, jak i fonetycznym. Z fonologicznego punktu widzenia o redukcji mówimy w sytuacjach, kiedy w określonej pozycji (jak poza akcentem) fonetycznie rozróżniana jest mniejsza liczba fonemów. Redukcja w sensie fonetycznym oznacza wyrazistą słuchowo zmianę barwy i innych cech głosowych w kierunku artykulacji mniej skrajnej (peryferyjnej), najczęściej centralizację lub skrócenie. Skrajnym przypadkiem redukcji jest elizja samogłoski.

Zagadnieniom redukcji w gwarach kaszubskich najwięcej uwagi poświęciła Zuzanna Topolińska, często posługująca się tu określeniem ,tendencja do różnicowania systemu wokalicznego pod i poza akcentem” (Topolińska 1969: 86). Pisze ona: „Za cechę wyróżniającą, definicyjną dialektów północnokaszubskich w opozycji do centralno- czy południowokaszubskich przyjęłam redukcję systemu wokalicznego w pozycji poza akcentem. Redukcję tę różne zespoły gwarowe przeprowadzają w różny sposób" (Topolińska 1969: 67) oraz „Za konwencjonalne granice tego zespołu przyjąć można [...] na północy [...] północną granicę występowania jednolitego systemu wokalicznego, identycznego w zasadzie w pozycji pod-i pozaakcentowej. W zasadzie, gdyż również Kaszuby centralne i południowe znają wypadki uzależnienia wokalizmu od akcentu, jest to jednak z reguły sprawa różnej frekwencji wariantów fakultatywnych, podczas gdy na północy w grę wchodzą 
warianty ściśle kombinatoryczne oraz ograniczenia pozycyjne poszczególnych fonemów" (Topolińska 1967: 88). Oczywiście różne obszary gwarowe realizują tendencję do redukcji (czy właściwie różnicowania wymowy w zależności od akcentu) w różny sposób. Wszystkie omawiane przez autorkę zjawiska o charakterze synchronicznym to (1) wymowa dyftongiczna $*[0]$ po marginalnych pod akcentem przy tendencji do wymowy monoftongicznej lub nierozróżniania wymowy po marginalnych i niemarginalnych poza akcentem, (2) tendencja do wymowy dyftongicznej samogłosek średnich $(*[\varepsilon, \rho, e:, o:]$ oraz rzadziej *[a:]) pod akcentem, (3) wyraźna skłonność do wymowy nieakcentowanego *[ə] jak *[ع], (4) zalążkowa tendencja do wymowy *[e:, a:] jak *[ع] poza akcentem, (5) skłonność do wymowy nieakcentowanego *[i] po twardych jak [?]], (6) tendencja do denazalizacji lub identyfikacji obu nosówek w nieakcentowanym wygłosie, (7) występowanie zaokrąglonego kontynuantu $*[\varepsilon]$ po miękkich w Borze tylko pod akcentem, (8) pełna elizja niektórych samogłosek (Topolińska 1969: 83, 84, 88, 90, 91, 92). Tendencję do wymowy dyftongicznej samogłosek średnich dostrzegała Z. Topolińska również na północy obszaru CK (w jej własnej definicji), m.in. na obszarze gwary luzińskiej. Mówi tu ona o nawiązaniu do zjawisk PK (Topolińska 1967: 120).

Współcześnie w gwarach CK (łącznie ze S) obserwujemy współcześnie bardzo wyraźnie redukcję fonologiczną nieakcentowanego $*[ə]$. Pod przyciskiem głoska ta wymawiana jest jak [Â], wymowa taka poza akcentem zachowuje się ogólnie rzadko ${ }^{25}$, częściej tylko u pojedynczych osób (wykazujących ogólnie wymowę staranną). W przeważającej większości przypadków słyszymy tu głoskę identyczną z kontynuantem *[ع], czyli niezbyt peryferyjne, lekko cofnięte $[\varepsilon]$. Czasami, częściej tylko indywidualnie $*[\varepsilon$, ə] ulegają też pewnej centralizacji, ale nie jest ona szczególnie silna, a przede wszystkim występuje tylko u niektórych osób. Sądząc po dotychczasowych opisach, są to zjawiska dość świeżej daty. Żadnych innych, nawet zarodkowych czy spontanicznych i bardzo rzadkich przejawów tendencji do redukcji czy ogólnie różnicowania wymowy samogłosek w zależności od akcentu na obszarze CK nie stwierdziłem.

Jeżeli chodzi o gwary PK, to skupię się na gwarze żarnowieckiej, stąd mam bowiem najbardziej usystematyzowane obserwacje i tu dysponuję wynikami analiz akustycznych. W pewnym zakresie będę jednak uzupełniał swój opis uwagami na temat wymowy zarejestrowanej przeze mnie w Chłapowie i Jastarni. Samogłoski * $[\varepsilon$, e:, o, o:], wymawiane pod

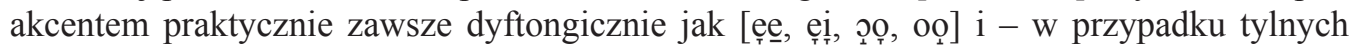
- z silną labializacją, tracą poza akcentem niemal konsekwentnie taką wymowę i przyjmują artykulację wyraźnie mniej peryferyczną. *[0] przyjmuje tu wymowę bardzo podobną do ogólnopolskiej lub wręcz z nią tożsamą, charakter fonetyczny $*[\varepsilon$, e:] należy omówić łącznie z pozostałymi samogłoskami przednimi. *[a:], realizowane pod akcentem jak [ө], traci niemal konsekwentnie zaokrąglenie i dzieli los typowy ogólnie dla pozostałych nieakcentowanych nietylnych. Ten sam kierunek rozwoju fonetycznego wykazuje *[ə], wymawiane tu pod akcentem jak $[a, æ]$ i nowy fonem, powstały z samogłoskowego kontynuantu dawnej nosówki krótkiej w śródgłosie, realizowany jak $\left[{ }^{2}\right]^{26}$. Rzecz dotyczy w pewnym zakre-

25 I chyba tylko wtedy, kiedy dany morfem czy część morfemu może się pojawić pod akcentem.

${ }^{26}$ Co ciekawe, Z. Topolińska (1955: 390) stwierdza, iż nawet w systemach z *[ə] wymawianym pod akcentem jak [æ] możliwe jest brzmienie $e$ poza akcentem. Możliwe, że autorka zarejestrowała początki omawianej tu redukcji. Możliwych wytłumaczeń jest tu jednak kilka. 
sie również $*[i]$. W zakresie fonologicznym mamy tu - w zależności od fonemu - silniejszą lub słabszą tendencję do nierozróżniania tych wszystkich samogłosek (czyli *[i, $\varepsilon$, e:, ə, ã $(-\mathrm{N})$, a:] poza akcentem. Ale na tym rzecz się nie kończy. Obserwujemy tu mianowicie bardzo silną centralizację. Jeżeli mianowicie do redukcji dochodzi (co czasami nie dotyczy *[e:] i jest stosunkowo rzadkie w przypadku *[i]), to celem artykulacyjnym są tu samogłoski centralne typu [3̧, əิ, ๆฺ]. Jest to bardzo wyraźnie uchwytne słuchowo, wątpliwości nie pozostawiają również wyniki analiz akustycznych. Zjawisko takie zaobserwowałem również w Chłapowie i Jastarni - być może nie z taką częstotliwością, ale w takiej samej formie fonetycznej - w przypadku *[E], *[ə] oraz chyba nieco rzadziej ustnego kontynuantu *[ã]. Poza tym w gwarze żarnowieckiej u informatorki w wieku średnim dochodzi do głosu bardzo wyraźnie tendencja do nieodróżniania poza akcentem wymowy *[o] po marginalnych i niemarginalnych (na miejscu dyftongu po marginalnych występuje tu monoftong). U niej również poza akcentem zmianie ulega wymowa *[a]: zamiast akcentowanego wybitnie tylnego i labializowanego [p] występuje tylno-centralne i niezaokrąglone [a]. Jeżeli w pełni zaufamy starszym opisom, to możemy stwierdzić, że tendencja do różnicowania samogłosek pod i poza akcentem przybrała na sile: część zjawisk obserwowanych już dawniej mocno się rozwinęła (w niektórych przypadkach zalążkowe wówczas tendencje rozpowszechniły się bezwyjątkowo), poza tym wykształciły się tu osobliwości nowe.

Przejdźmy do gwary luzińskiej. Dyftongiczną wymowę akcentowanych średnich stwierdziłem tylko $\mathrm{u} *[\varepsilon]([\underline{\varepsilon}])$ i $*[\mathrm{o}:]([\mathrm{ou}])$ i to rzadko. W tym zakresie nie doszło więc do żadnych dramatycznych zmian, znanych progresywnym gwarom PK. Nie należy tu jednak zapominać o tym, że *[ع] uległo ogólnemu wyraźnemu podwyższeniu, przy czym to samo dotyczy prawdopodobnie $*[\mathrm{e}:] \mathrm{i} *[\mathrm{o}:]$.

Ciekawym zjawiskiem jest przeciętnie wyraźnie opuszczona wymowa [o:] poza akcentem. Oprócz wymowy bardzo wąskiej [ự, o], tożsamej z typową dla pozycji akcentowej, występują tu często wymowy wyraźnie otwarte typu [o], identyczne z realizacjami *[a:] i tylnego monoftongicznego kontynuantu *[o]. Wymowa taka notowana była sporadycznie już kiedyś (AJK 14: 81), nie występowała jednak w tak regularny sposób i nie była uzależniona od akcentu. To - najprawdopodobniej stosunkowo nowe - zjawisko można bez wątpienia zakwalifikować do redukcji zarówno w sensie fonologicznym, jak i fonetycznym.

Przejdźmy do $*[\varepsilon] \mathrm{i} *[ə]$. W literaturze dostrzegano już tendencję do redukcji fonologicznej i fonetycznej *[ə] na północy. Hanna Popowska-Taborska (1961: 52) stwierdza, że wariantem *[ə] poza akcentem jest ,najczęściej dźwięk bliski lub wprost równy e, często (szczególnie na północy) silnie zredukowany. Owo zredukowane pozaakcentowe $e$ ulega słabszemu lub silniejszemu zwężeniu [...]”. Zwrócić tu należy uwagę na pewną ważną rzecz. Badaczka mówi tu o utożsamieniu się *[ə] $\mathrm{z} *[\varepsilon]$ lub zbliżeniu się do niego poza akcentem, jednocześnie mówiąc o silnie zredukowanej i zwężonej wymowie *[ə] w tejże pozycji. Nie jest tu jednak jasne, co tak naprawdę dzieje się z $*[\varepsilon]$. Jeśli nie ulegałoby ono żadnym zmianom, to opis ten byłby wewnętrznie sprzeczny. Jeśli zaś ulegałoby, to informacja taka - wyrażona eksplicytnie - powinna się tu pojawić, co się jednak nie dzieje. Sytuacja we współczesnym materiale jest jasna. Poza akcentem dochodzi tu niemal bezwyjątkowo nie tylko do redukcji $*[\partial] \mathrm{i} *[\varepsilon] \mathrm{w}$ sensie fonologicznym, ale również do bardzo wyraźnej centralizacji fonetycznej. Ulega jej zresztą na równi monoftongiczny przedni 
kontynuant $*[0]$ po niemarginalnych (stanowiący synchronicznie alofon /o/). Rezultatem jest głoska typu [ə], być może minimalnie przesunięta w przód. Właściwą sobie wymowę

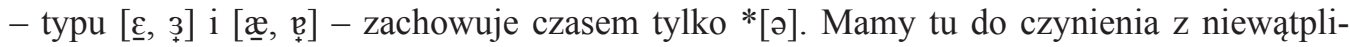
wym, zdecydowanym nawiązaniem do wymowy PK.

Do redukcji zaliczyć można również wspólną dla gwary luzińskiej i obszaru PK wymowę scentralizowaną *[i] w wygłosie poza akcentem (głównie po twardych lub stwardniałych).

Redukcja samogłoskowa nie tworzy w gwarze luzińskiej tak obszernego zestawu zjawisk, jak w najbardziej progresywnych gwarach PK. Niemniej jednak można przypuszczać, iż w ciągu ostatnich kilkudziesięciu lat uległa pewnemu wzmocnieniu, które doprowadziło do stanu podobnego jak w gwarach mniej progresywnych tego obszaru. Mamy tu wyraźne nawiązania zarówno pod względem objętych zmianami fonemów, jak i kierunków rozwoju fonetycznego. Bez wątpienia zróżnicowanie samogłosek nieakcentowanych i akcentowanych jest w gwarze luzińskiej o wiele wyraźniejsze niż w gwarach CK.

\section{Zjawiska konsonantyczne}

\subsection{Rozwój * [kj, gj]}

Gwary kaszubskie wraz z Krajną i Borami Tucholskimi objęła tendencja do afrykatyzacji zmiękczonych welarnych $*\left[\mathrm{k}^{\mathrm{j}}, \mathrm{gj}\right]$. Geneza i chronologia tego procesu jest sporna (Smoczyński 1958; Górnowicz 1971), bardzo prawdopodobne jest przy tym, iż pierwotnym ogniskiem zmian były lokalne gwary niemieckie (Jocz 2012b). Materiały AJK ukazują bogactwo kontynuantów * $\left[\mathrm{k}^{\mathrm{j}}, \mathrm{g}\right] \mathrm{z}$ z wahaniami w poszczególnych punktach terenowych, ale mimo wszystko również z zauważalnym zróżnicowaniem gwarowym (AJK 14: 177-181, mapy 689-690).

$\mathrm{Na}$ całych CK typową wymową są obecnie postalweolarne afrykaty [t $\int$, d3] o słabszej lub silniejszej miękkości. Wymowa bliska lub wręcz tożsama $\mathrm{z}[\mathrm{t} 6, \mathrm{~d} \mathrm{~b}]$ możliwa jest tu $\mathrm{z}$ racji na to, iż każde $/ \int, 3, \mathrm{t} \int \mathrm{d} 3 /$, niezależnie od pochodzenia, może być wymawiane $\mathrm{z}$ bardzo silną miękkością jak lub niemal jak $[6, \mathrm{z}, \mathrm{t} 6, \mathrm{~d} z]$. Pojawiają się tu też fakultatywnie realizacje twarde [ts, dz], tak samo zresztą jak w przypadku każdego $/ \int, 3, \mathrm{t}$, dz/. Wymowa [t $\left.\int, d 3\right]$ (wraz ze stwardniałymi [ts, dz]) jest bez wątpienia wymową najbardziej wyewoluowaną, będącą ostatnim ogniwem łańcucha $\left[\mathrm{k}^{\mathrm{j}}, \mathrm{g}\right] \rightarrow[\mathrm{c}, \mathrm{J}] \rightarrow[\mathrm{cç}, \mathrm{jj}] \rightarrow[\mathrm{t} 6, \mathrm{~d} z] \rightarrow\left[\mathrm{t} \int\right.$, $\mathrm{d} 3](\rightarrow[\mathrm{ts}, \mathrm{dz}])(\mathrm{Jocz} 2012 \mathrm{c})$.

$\mathrm{Na}$ obszarze PK rzecz nie przedstawia się całkiem jednolicie. U większości informatorów obserwujemy konsekwentną chyba afrykatyzację, przy czym wymowa $\mathrm{z}$ alweolarno -palatalna [t6, dz] konkuruje z postalweolarną [t $\int$, dz]. Pierwszy typ przeważa, choć jednocześnie $*[\mathrm{~g}]$ wykazuje chyba nieco silniejszą tendencję do wymowy drugiego rodzaju: òdżin ['wọdzĩn] 'ogień', dtudżi ['dlidzọ̦] 'długi', cenczi [tsọn'tti] 'cienki', szeroczi ['ọ̣' rotci] 'szeroki', daleczé [de'lętci] 'dalekie' (Chłapowo), òdżin ['wọdzin] 'ogień', dtudżi ['dlydzı] 'długi', cenczi [tsọn'tci] 'cienki', szeroczi [ş' rotci] 'szeroki', nadżi [ne'dzi] 'nagi' (Chłapowo), òdżin ['wedzin] 'ogień', dhudżi ['dlüdzi] 'długi', cenczi [tsọ̃n'țẹi] 'cienki', szeroczi [ş'rotti] 'szeroki' (Jastarnia), òdżin ['wydż̃n] 'ogień', dludżi ['dludzi] 'długi', cenczi [tsọn'tfêr] 'cienki', szeroczi [şê้'rotci] 'szeroki', daleczé [dä'lọtci] 'dalekie', blisczé ['blistci] 'bliskie' (Jastarnia), òdżin ['wọdżın] 'ogień', dłudżi ['duydzi] 'długi', cenczi [tsọn'tfi] 


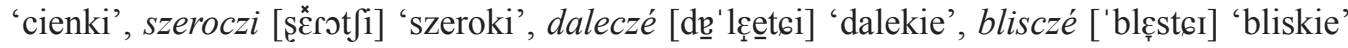
(Nadole). Informator z Wierzchucina nie ma tu natomiast afrykat w ogóle, do czynienia mamy tu głównie z mocno zmiękczonymi welarnymi: òdżin ['weg'in] 'ogień', dłudżi ['dwụgi] 'długi', cenczi [tsọn'kij] 'cienki', szeroczi [ş̣' rokji] 'szeroki'. Jako wspólny mianownik można dla PK przyjąć ogólnie słabsze wyewoluowanie wymowy niż na CK.

U obu informatorów z Luzina stwierdziłem zupełny brak afrykat i zazwyczaj dość słabo zmiękczone welarne na miejscu $*\left[\mathrm{k}^{\mathrm{j}}\right.$, g] (przy czym *[i] nierzadko przyjmuje tu wymowę bardziej otwartą): òdżin ['wэgın] 'ogień', dhudżi ['dwugọ] 'długi', cenczi ['tsọnḳı]

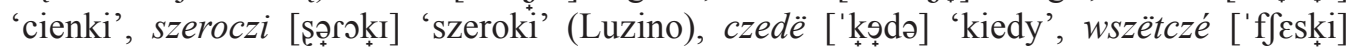

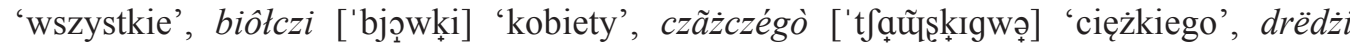
['dreg̣I] 'drugi', czija ['ci.a, 'ḳi.a] 'kija'. U informatora z Częstkowa zanotowałem z nielicznymi wyjątkami afrykatyzację, której rezultatem są [tø, dz]]: òdżin ['wэdzin] 'ogień', dludżi ['dwugi] 'długi', cenczi [tsọntci] 'cienki', szeroczi [sə̣' rotci] 'szeroki', daleczé [dạ'lọtci] 'dalekie', słodczi ['swọttci] 'słodki'. Brak afrykatyzacji i twardnienie *[k', gi] w Luzinie obserwował już Smoczyński. Jego opis (oraz analiza starszych opracowań) pozwala założyć, iż tendencja do palatalizacji i afrykatyzacji dotarła do gwary luzińskiej, ale przynajmniej na części obszaru nie wykształciła się tu w pełni, a następnie uległa całkowitemu cofnięciu, prowadzącego nawet do restytucji dawnej wymowy [kọ, gọ]] (Smoczyński 1955: 82; Nitsch 1903: 240).

Z całą pewnością można tu stwierdzić, iż gwara luzińska (1) nie uczestniczyła w części najnowszych innowacji, które objęły wymowę * $\left[\mathrm{k}^{\mathrm{j}}, \mathrm{g}\right] \mathrm{w}$ gwarach CK. Zachowanie wymowy bardziej archaicznej oraz być może tendencja do wycofywania przeprowadzonych już innowacji (2) łączy gwarę luzińską z częścią przyległych gwar PK, por. (AJK 14: 177-181, mapy 689-690).

\section{Zjawiska prozodyczne}

\subsection{Sila akcentu}

Omówione już powyżej zjawiska redukcji samogłoskowej w gwarach PK przypisywane są typowemu dla tego obszaru silnemu akcentowi ekspiratorycznemu. Z. Topolińska, omawiając akcent PK, mówi przy tym o jego wpływie zarówno na barwę, jak i długość samogłosek (Topolińska 1958: 389-390). Zaznaczyć tu należy, że definicja PK przyjęta przez Z. Topolińską we wspomnianym właśnie artykule - opierająca się wyłącznie na zjawiskach akcentowych i dzieląca gwary kaszubskie tylko na dwa obszary (północny i południowy) - różni się od innych definicji PK. W zasadzie znaczna część gwar CK (poza wschodnimi na południe od Kartuz) należy w przyjętym przez badaczkę rozumieniu do obszaru PK (Topolińska 1958: 381, przypis 2, 382, przypis 3,391), choć omawiane przez nią zjawiska „apofonii kwalitatywnej i kwantytatywnej” pochodzą raczej z obszaru PK w znaczeniu ogólnie przyjętym (Topolińska 1958: 389-390). Paweł Smoczyński stwierdza w Luzinie wytworzenie się „silnego przycisku wyrazowego” (Smoczyński 1955: 82).

Ukierunkowanych badań korelatów akcentu w kaszubszczyźnie nie prowadziłem (dysponuję tylko bardzo ogólnymi danymi dla $\mathrm{CK}$ ), swe (bardzo) ogólne rozważania oprę więc na wrażeniach słuchowych i ogólnych (wzrokowych) analizach akustycznych. 
Akcent CK nie różni się audytywnie od polskiego. Podobnie jak w przypadku polszczyzny niewątpliwymi korelatami akustycznymi akcentu są tu średnio nieco większa długość trwania samogłosek oraz wyższy ton podstawowy. Jeżeli chodzi o natężenie dźwięku, to brak zauważalnych różnic pomiędzy akcentowanymi i nieakcentowanymi w śródgłosie, tylko niekcentowane w wygłosie wykazują skłonność do niższych wartości tej zmiennej. U nagranych przeze mnie informatorów z Chłapowa i Jastarni akcent jest podobny do polskiego czy CK. Nieco bardziej wyraźną rolę odgrywa tu natężenie dźwięku, brak jednak jakichkolwiek zasadniczych i uderzających różnic. Odmiennie ma się rzecz w Wierzchucinie i Nadolu, gdzie siła akcentu od razu zwróciła moją uwagę. Różnica natężenia dźwięku pomiędzy akcentowanymi a nieakcentowanymi jest tu wyraźna, co ciągnie za sobą spore różnice ilościowe (szczególnie w przypadku*[a], a zwłaszcza *[o, o:], ulegających pod akcentem wyraźnemu wzdłużeniu $)^{27}$. Mniejszą rolę wydaje się również w tej gwarze odgrywać przebieg tonu podstawowego. W gwarze luzińskiej tak silnego akcentu nie stwierdziłem. Podobnie jak w Chłapowie i Jastarni, ekspiracja odgrywa tu chyba nieco większą rolę niż w polszczyźnie i na $\mathrm{CK}$, ale nie jest to różnica bardzo znacząca i wolałbym jej nie absolutyzować.

Na podstawie dostępnych mi danych nie mogę współcześnie stwierdzić pokrywania się granic ugrupowań dialektalnych z granicami dzielącymi obszary o odmiennej przyrodzie fonetycznej akcentu. Jeżeli zawierzyć starszym opisom, to w ciągu ostatnich kilkudziesięciu lat doszło na znacznej części obszaru kaszubskiego do wycofania się silnego akcentu ekspiratorycznego na rzecz akcentu słabszego o mieszanym charakterze fonetycznym (z tej perspektywy akcent w gwarze żarnowieckiej byłby archaizmem peryferycznym). Należy tu również obszar gwary luzińskiej. Tendencja ta objęła jednak nie tylko gwary CK, ale również znaczną część gwar PK, kwestia siły akcentu nie może być więc ostatecznie istotna dla naszych rozważań.

\subsection{Miejsce akcentu}

Wspomniany już powyżej podział gwar kaszubskich pod względem akcentowym na obszar południowy i północny uzasadniony był miejscem akcentu. Południe charakteryzowało się ogólnie stabilizacją akcentu na sylabie pierwszej, północ zaś zachowaniem akcentu swobodnego i ruchomego. Do pierwszego obszaru należeć miała przy tym południowo -wschodnia część obszaru CK, choć zachowywać się tu miały relikty swobody akcentu w pewnych charakterystycznych kategoriach słowotwórczych. Drugi obszar nie był pod względem miejsca akcentu jednolity, pewne cechy typowe były dla jego całości, inne natomiast występowały tylko na mniej lub bardziej ograniczonych północnych obszarach peryferyjnych. Ogólnie starsze opisy stwierdzają ekspansywność akcentuacji inicjalnej, stopniowe wycofywanie się wielu archaicznych typów akcentuacyjnych na północ oraz postępującą zatratę (systemowej) ruchomości akcentu (Topolińska 1958; Korytkowska 1979).

Również w tym zakresie dysponuję dla obszaru PK dość ograniczonym materiałem, nie prowadziłem też ukierunkowanych badań akcentu w gwarze luzińskiej, moja analiza bę-

${ }^{27}$ Stąd też zapewne w gwarze żarnowieckiej o wiele silniej wyrażona jest redukcja jakościowa. 
dzie więc siłą rzeczy dość ogólna i fragmentaryczna. Zagadnienia współczesnej prozodii gwar kaszubskich powinny stać się bez wątpienia przedmiotem specjalnych badań.

Na północno-zachodniej części obszaru CK bardzo dobrze zachowuje się akcent swobodny z wyraźną skłonnością do akcentu kolumnowego, choć nadal charakteryzujący się ograniczoną ruchomością. Wyróżnia się tu kilka kategorii słowotwórczych. Pierwszym typem jest bù'dink i pokrewny mu wò'zyk z oksytonezą w mianowniku. Drugim są rzeczowniki odczasownikowe typu kô'zanié i pokrewne im imiesłowy przymiotnikowe zakô'zóny. Trzecią klasę tworzą liczebniki $d w a$ 'nôsce, trzë'nôsce. Kolejną grupą są rzeczowniki na *-ęt-, akcentowane w liczbie pojedynczej na sylabę pierwszą ('dzéwczãa, 'dzéwczëca), a w liczbie mnogiej na tę cząstkę (dzéw'czãta), co może generować oksytonezę (dzéw'czãt). Dobrze chyba trzyma się ruchomość w przypadku 'kòlano (liczba pojedyncza), kò'lana (liczba mnoga). Ale również poza tymi klasami brak u rzeczowników jakiejkolwiek zasady, niektóre akcentowane są konsekwentnie na pierwszą sylabę rdzenia ('niedzela, 'niedzelë), inne zaś na drugą (ma'lëna, ma'lënë). Czasami ruchomość wywołana jest tendencją do unikania oksytonów poza wymienionymi powyżej klasami (Ka'szëbe, Ka'szëbów, $K a$ 'szëbama, ale 'Kaszëb). Wariantywność akcentuacji niektórych rzeczowników jest prawdopodobnie reliktem ruchomości akcentu ('robòta, 'robòtã, 'robòtë obok ro'bòta, ro'bòtã, ro'bòtë). Warto tu zwrócić uwagę na akcentuację kolumnową w nowszych zapożyczeniach, $\mathrm{np}$. tele'wizor, tele'wizorë. Nieprzewidywalna ruchomość akcentu występuje również w innych częściach mowy. Np. formy niektórych przysłówków na $-n-\mathrm{w}$ stopniu wyższym wykazują oksytonezę (piã'kni, dro'bni), inne zaś nie ('pózni). Jeżeli chodzi o czasowniki, to większość form bezprzedrostkowych (niemotywowanych) przyjmuje akcent inicjalny bez jakiejkolwiek ruchomości ('gadac, 'gôdóm, 'gôdôta, 'gôdaja, 'gôdelë, 'bùdowac, 'bùdëje, 'bùdëja, 'bùdowelë...). W przypadku czasowników przedrostkowych mamy do czynienia z ciekawą zależnością: formy niedokonane akcentowane są na rdzeń, akcentowane zaś na przedrostek, np. 'pòwtórzi wobec pòw'tôrzô, 'òbrócy wobec ò'brôcô czy 'wëgniece wobec wë'gniôtô. Akcent przenosi się przy tym na negację tylko w czasownikach niemotywowanych i przedrostkowych dokonanych ('nie gôdaja, 'nie wëszedt), w czasownikach przedrostkowych pozostaje na rdzeniu (nie do'cérô). Wyjątki od tych reguł występują, ale są przypadkowe i nieliczne. Jeżeli chodzi o południowo-wschodnią część obszaru $\mathrm{CK}$, to nie mogę się raczej zgodzić z oceną dotychczasowych badaczy, widzących tu systemowy akcent inicjalny przy bardzo rzadkich reliktach dawnego akcentu swobodnego. Tendencja do akcentu inicjalnego jest tu co prawda bardzo silna, w przebadanym materiale w ok. $20 \%$ form z tego terenu stwierdziłem jednak archaiczną wymowę nieinicjalną we wszystkich wymienionych powyżej klasach słowotwórczych (przy czym np. typ bu'dink wydaje się bardzo stabilny).

W gwarach PK zwraca uwagę przede wszystkich lepsze zachowanie archaicznej oksytonezy. W pierwszym rzędzie wymienić należy przymiotniki. Do dzisiaj panuje tu w zasadzie akcentuacja typu 'biôłi, 'dludżi, ze'lony, sze' roczi, żôt'ti, cen'czi, mło'di, tã' pi, së'chi, $n o ' w i$, mio'dny. Niezależnie od gwary i wieku informatora pojawia się jednak również wymowa 'żôtti, 'miodny, 'tãpi, 'młodi. Dobrze trzyma się akcentuacja rozkaźników sta' nita, sa'dnita so. Nie stwierdziłem też żadnych zachwiań w typie ka'miszk czy zrze'szony oraz przesunięć akcentu w rzeczownikach jak bra'cyna, bra'cynowie. Akcent oksytoniczny w rozkaźnikach stë'chôj, òddë'chôj zaobserwowałem tylko w Jastarni, i tu zresztą fakultatywnie. Podobnie nieobligatoryjne akcentowanie na sylabę ostatnią $\mathrm{w}$ formach czasowni- 
kowych jak pli'wôt czy pli'wi zaobserwowałem tylko w Wierzchucinie. Ruchomość w przypadku 'jezoro, je' zora (1. mn.) stwierdziłem tylko u starszego informatora w Jastarni. Brak konsekwencji w wymowie 'kòlano obok kò'lano na całym obszarze PK jest prawdopodobnie reliktem ruchomości $\mathrm{w}$ danym paradygmacie.

Przejdźmy do gwary luzińskiej. Już starsze opisy (Topolińska 1958; Korytkowska 1979) wskazują, że interesująca nas gwara leży na peryferiach akcentuacyjnych archaizmów PK. Niektóre typy mają tu być rzadkie lub nie występować już zgoła w ogóle. P. Smoczyński stwierdza tu tendencję do akcentu inicjalnego (Smoczyński 1955: 82). W pierwszym rzędzie stwierdzić (lub potwierdzić) należy całkowite wycofanie się oksytonicznych przymiotników (początki tego procesu obserwował zresztą już Nitsch (1903: 243)). W moim materiale występuje wyłącznie wymowa typu 'biôti, ze'lony, 'żôtti, 'dtudżi, 'cenczi, sze'roczi, 'tãpi, 'młodi, 'żëwi, 'sëchi, 'nowi. Wyraźnie dominuje też akcentuacja typu 'wicy, tylko wyjątkowo zarejestrowałem wymowę pro'scy. Bardzo dobrze trzyma się archaiczna wymowa w typach bù'dink, zwiq'zóny, pòchò'dzenié i piã'tnôsce. Dotyczy to prawdopodobnie również klasy 'dzéwczã, dzéw'czãta. W wymowie 'kòlano obok kò'lano czy 'sobòtã obok so'bòtã brak jakiejkolwiek konsekwencji. Ogólnie akcentuacja imion i przysłówków w gwarze luzińskiej nie różni się zasadniczo od tej typowej dla obszaru ZCK. Przejdźmy do czasowników. Najprawdopodobniej w ciągu ostatnich kilkudziesięciu lat rozpowszechniła się w gwarze luzińskiej wymowa 'sadnita. Brak tu też oksytonezy w przypadkach jak 'ptëwôt czy 'stëchôj. Bardzo często akcentuacja luzińska jest tożsama z ZCK. Czasowniki niemotywowane najczęściej akcentowane są na sylabę pierwszą (np. 'widzałë, 'nekalë, 'chòdzelë, 'kôzelë, 'bawilë sã), przedrostkowe dokonane na przedrostek (np. 'wëkòpalë, 'przëjachôt, 'pòdpisôt, 'ùkredlë, 'wëgrelë), a przedrostkowe niedokonane na rdzeń (np. sã roz'wijồ, òb'zerac, na' griwac, roz'rôstô, przë'jéżdżôt). Tak samo zachowuje się też akcent przy negacji (np. 'nie wiedzôt, 'nie doroslë wobec nie za'rôbiôt). Pojawiają się tu również nieregularne odstępstwa od tych reguł i dublety (np. ù'prawic, do'jachac, od' lecy, przë'jãlë czy 'obleklë obok òb'leklë lub sã 'ùrodzëc obok sã ù'rodzëc), co nieobce jednak gwarom ZCK. Niemniej jednak w gwarze luzińskiej pojawia się tu regularnie akcentuacja, całkowicie obca CK. Inaczej są tu akcentowane czasowniki na -owa- (np. pró'bòwôt, pró'bùjemë, zapla'nëjemë, bù'dëjã) oraz część form czasowników na -a- (np. gô'daja, narzé'kaja, pòchô'daja, pòdchô'dalë, doras'talë, nalô'zalë, dostô'walë, òtmi'kalë, gô'dalë, przëchô'dalë, przëchô'dało). Osobno należy zwrócić uwagę na formę pa'miãtóm. Mamy tu do czynienia $\mathrm{z}$ archaizmami lub ewentualnie z innowacjami będącymi skutkiem uogólnienia morfologicznego archaizmów na cały paradygmat (Bronisch 1896: 43-48; Nitsch 1903: 244).

Pod względem miejsca akcentu mamy na Kaszubach do czynienia z podziałem na południowy obszar innowacyjny i północny archaizujący. Podział ten nie tylko nie pokrywa się z podziałem na podstawowe ugrupowania dialektalne (południe, centrum, północ), ale przecina nawet obszar tak jednolity językowo jak CK. Zanik cech archaicznych (przesuwanie izofon dalej na północ i pewne rozchwianie pojawiające się nawet na peryferiach północnych) wydaje się (powoli) postępować, przy czym tendencje do zaniku konkretnych archaizmów są często dość stare. Nie sposób określić tu ogniska zmian, mamy tu w zasadzie do czynienia z ogólnokaszubską tendencją do uproszczenia akcentuacji i zaniku pewnych nacechowanych archaizmów. Jedyną innowacją może tu być uzależnienie akcentu czasowników od struktury słowotwórczej i aspektu. Na obecną chwilę nie mam jednak 
stuprocentowej pewności, czy jest to rzeczywiście zjawisko nowe i nie wiem, jaki ma zasięg na północ od CK. W świetle powyższych faktów i dostępnego materiału nie sposób stwierdzić jednoznacznych nawiązań gwary luzińskiej do obszaru CK czy PK.

\section{Podsumowanie}

Podsumowanie rozpocznę od streszczenia powyższych ustaleń $\mathrm{w}$ formie tabelarycznej (tabela 1). Poszczególne relewantne zjawiska fonetyczne wyszczególnione są w lewej kolumnie. Kolejne kolumny określają, czy stan w gwarze luzińskiej określić należy jako archaizm lub innowację CK czy innowację lub archaizm PK. W przypadku całkowitej pewności co do oceny umieszczam w odpowiedniej komórce wartość „,+1” (zgodność) lub ,-1" (niezgodność), jeżeli ocena jest niepewna lub ambiwalentna czy nawiązanie niepełne ,$-{ }^{+1} / 2$ ” lub ,,$-1 / 2$ ". W przypadku obojętności wpisuję ,0”. Oznaczenie „L” odpowiada rozwojowi specyficznie luzińskiemu. W ostatnim wierszu znajduje się suma ocen.

Tabela 1. Tabela podsumowująca

\begin{tabular}{|l|c|c|c|c|}
\hline \multirow{2}{*}{ Cecha } & \multicolumn{2}{|c|}{ CK } & \multicolumn{2}{c|}{ PK } \\
\cline { 2 - 5 } & archaizm & innowacja & innowacja & archaizm \\
\hline$*[\mathrm{i}, \mathrm{i}]$ & 0 & -1 & +1 & 0 \\
\hline$*[\mathrm{e}:]$ & 0 & -1 & +1 & +1 \\
\hline$*[\varepsilon]$ & 0 & 0 & +1 & 0 \\
\hline$*[\mathrm{a}]$ & 0 & 0 & $\mathrm{~L}$ & $\mathrm{~L}$ \\
\hline$*[\mathrm{a}:]$ & $\mathrm{L}$ & $\mathrm{L}$ & +1 & 0 \\
\hline$*[0]$ po niemarg. & 0 & 0 & $+1 / 2$ & +1 \\
\hline$*[\mathrm{o}:]$ & 0 & -1 & $\mathrm{~L}$ & $\mathrm{~L}$ \\
\hline$*[\mathrm{u}]$ & $\mathrm{L}$ & $\mathrm{L}$ & +1 & 0 \\
\hline$*[ə]$ & 0 & -1 & -1 & 0 \\
\hline barwa $*[\tilde{a}]$ & +1 & -1 & 0 & +1 \\
\hline barwa $*[\tilde{o}]$ & 0 & -1 & +1 & 0 \\
\hline nosowość $*[\tilde{a}, \tilde{o}]$ & 0 & -1 & +1 & 0 \\
\hline red. fonologiczna & 0 & +1 & +1 & 0 \\
\hline red. fonetyczna & 0 & 0 & $+1 / 2$ & 0 \\
\hline$*[\mathrm{k}$, gij] & 0 & -1 & 9 & 3 \\
\hline SUMA & 1 & -7 & & \\
\hline
\end{tabular}

Z rdzennym obszarem CK gwarę luzińską w zakresie relewantnych cech łączy 1 archaizm i dzieli od niego 7 innowacji, których interesująca gwara nie zna, a których ogniskiem były CK. Gwara S różni się od rdzennego obszaru CK tylko w zakresie braku innowacyjnych barw *[ã] (archaizm wspólny z gwarą luzińską) i konsonantyzacją nosowości (brak innowacji CK i wspólna z gwarą luzińską innowacja PK), cechami ważnymi, ale nielicznymi. Z PK zespołem dialektalnym łączą interesującą nas gwarę 3 archaizmy i 9 innowa- 
cji. Wszystko to przy 2 zmianach głosowych typowych tylko dla gwary luzińskiej i odcinających ją zarówno od CK, jak i PK.

Trudno tu więc o jakiekolwiek wątpliwości co do umiejscowienia gwary luzińskiej wśród gwar kaszubskich pod względem zjawisk fonetycznych. Trzeba tu podkreślić, że wiele z uwzględnionych tu procesów głosowych jest stosunkowo świeżej daty, co wskazuje na aktualne związki pomiędzy rozpatrywanymi obszarami gwarowymi. Z racji na umiejscowienie geograficzne gwary zjawiska często nie przybierają tu tak ekstremalnych form jak niejednokrotnie na peryferiach północnych. Niemniej jednak gwarę luzińską sklasyfikować należy z interesującej nas w niniejszym artykule perspektywy bez wątpienia jako gwarę PK. Oczywiście w ramach tego zespołu dialektalnego jest ona gwarą marginalną, która nie charakteryzuje się wyjątkową progresywnością.

\section{Bibliografia}

AJK, Atlas językowy kaszubszczyzny i dialektów sąsiednich I-XV, red. Zespół Zakładu Słowianoznawstwa PAN, Wrocław - Warszawa - Kraków 1964-1978.

Biskupski L., 1883, Die Sprache der Brodnitzer Kaschuben im Kreise Karthaus (West-Preussen). H. 1: Lautlehre-Abteilung A, Leipzig.

Bronisch G., 1986, Kaschubische Dialectstudien. Die Sprache der Bëlôcë, Leipzig.

Dejna K., 1981, Atlas polskich innowacji dialektalnych, Warszawa - Łódź.

Dejna K., 1993, Dialekty polskie, Wrocław - Warszawa - Kraków.

Friedrich H., 1939, Gwara kurpiowska na tle Mazowsza i Mazurów Pruskich, Warszawa.

Górnowicz H., 1971, Zmiękczenie spółgłosek tylnojęzykowych w gwarach pólnocnopolskich, „Rozprawy Komisji Językowej Łódzkiego Towarzystwa Naukowego", XVII, s. 31-55.

Handke K., 1979, Wewnętrzne podziaty gwarowe Kaszub i sąsiednich terenów, w: J. Siatkowski (red.), Konferencja Pomorska (1978), Wrocław - Warszawa - Kraków - Gdańsk, s. 111-123.

Гильфердинг А., 1862, Остатки Славянъ на южномъ берегу Балтійскаго моря, Петерсбург.

Jocz L., 2012, O (nie)istnieniu samogłoski [i] w dialektach kaszubskich, w: E. Komorowska, K. Kondzioła-Pich, A. Ochrymowicz (red.), Komunikacja międzyludzka. Leksyka. Semantyka. Pragmatyka. III, Szczecin, s. 145-152.

Jocz L., 2012b, Wpływ fonetyczny i fonologiczny języka niemieckiego na tużycczyzne $i$ kaszubszczyznę $w$ kontekście słowiańskim. Wybrane problemy $w$ aspekcie porównawczym. Część II, „Acta Cassubiana” XIV, s. 43-58.

Jocz L., 2012c, Kilka uwag na temat statusu fonologicznego * $\left[k^{j}, g^{j}\right]$ w starszej $i$ współczesnej kaszubszczyźnie centralnej, „Linguistica Copernicana” 2(8), s. 117-126.

Jocz L., 2013, System samogłoskowy współczesnych gwar centralnokaszubskich, Szczecin.

Jocz L., 2014, System spółgłoskowy wspótczesnych gwar centralnokaszubskich, Szczecin.

Jocz L., 2015, Akcent wyrazowy we współczesnej kaszubszczyźnie centralnej, „Język Polski” 3, s. $260-296$.

Jocz L., 2015b, System samogłoskowy współczesnych gwar zaborskich, „Rocznik Slawistyczny” 64, s. $27-48$.

Jocz L., 2015c, System samogłoskowy współczesnej kaszubszczyzny północno-Zachodniej, „Slavia Occidentalis" 72/1, s. 39-63.

Jocz L., 2016, System samogłoskowy gwary luzińskiej, „Polonica” 36, s. 191-227.

Korytkowska M., 1979, Zasięgi zjawisk akcentowych na Kaszubach w świetle materiałów AJK, „Studia z Filologii Polskiej i Słowiańskiej” 18, s. 133-139.

Lorentz F., 1901, Zum Heisternester Dialekt, „Archiv für Slavische Philologie” 23, s. 106-112. 
Lorentz F., 1903, Slovinzische Grammatik, St. Petersburg.

Lorentz F., 1911, Zasady ogólnej pisowni i składni pomorsko-kaszubskiej, Toruń.

Lorentz F., 1913, Teksty pomorskie czyli stowińsko-kaszubskie. Zeszyt I, Kraków.

Lorentz F., 1925, Geschichte der pomoranischen (kaschubischen) Sprache, Berlin - Leipzig.

Lorentz F., 1927-1937, Gramatyka pomorska, Poznań.

Nitsch K., 1903, Studya kaszubskie: Gwara luzińska, „Materyały i prace Komisji Językowej Akademii Umiejętności w Krakowie" 1, s. 221-273.

Nitsch K., 1907, Dyalekty polskie Prus zachodnich, „Materyały i prace Komisji Językowej Akademii Umiejętności w Krakowie" 3, s. 101-284.

Nitsch K., 1908, Lorentz, a) Slovinzische Grammatik. b) Slovinzische Texte, „Rocznik Slawistyczny” 1, s. $121-130$.

Nitsch K., 1955, Pótnocno-polskie teksty gwarowe. Od Kaszub po Mazury, Kraków.

Nitsch K., 1957, Dialekty języka polskiego, Wrocław - Kraków.

Popowska-Taborska H., 1961, Centralne zagadnienie wokalizmu kaszubskiego. Kaszubska zmiana $e \geq i$ oraz $\breve{\imath}, \breve{y}, \breve{u} \geq 2$, Wrocław - Warszawa - Kraków.

Ramułt S., 1893, Słownik języka pomorskiego czyli kaszubskiego, Kraków.

Rzetelska-Feleszko E., 2009, O badaniu przeszłości dialektów kaszubskich (na podstawie Atlasu G. Wenkera), w: H. Popowska-Taborska, E. Rzetelska-Feleszko, Dialekty kaszubskie w świetle XIX-wiecznych materiałów archiwalnych. Prezentacja i opracowanie kaszubskich materiałów językowych zebranych przez Georga Wenkera w latach 1879-1887, Warszawa, s. 143-154.

Rzetelska-Feleszko E., 2009b, Zmiany $w$ kaszubskich kontynuantach *ā pomiędzy rokiem 1880 a 1955-1965, w: H. Popowska-Taborska, E. Rzetelska-Feleszko, Dialekty kaszubskie w świetle XIX-wiecznych materiałów archiwalnych. Prezentacja i opracowanie kaszubskich materiałów językowych zebranych przez Georga Wenkera w latach 1879-1887, Warszawa s. 155-170.

Sawicka I., 2007, Język polski, w: Komparacja współczesnych języków słowiańskich. Fonetyka i fonologia, red. I. Sawicka, Opole.

Siatkowski J., 1965, Geografia kontynuantów w kaszubszczyźnie na podstawie dawniejszych opracowań, „Studia z Filologii Polskiej i Słowiańskiej” 5, s. 407-413.

Smoczyński P., 1955, Zmiany językowe w Luzinie w ostatnich pięćdziesięciu latach, „Rozprawy Komisji Językowej Łódzkiego Towarzystwa Naukowego" 3, s. 77-85.

Smoczyński P., 1958, W sprawie zmian $k \dot{k}-g$ na Kaszubach $i$ w zachodnich dialektach pótnocno-polskich, „Studia z Filologii Polskiej i Słowiańskiej” 3, s. 61-79.

Stieber Z., 1951, Zagadnienie iloczasu kaszubskiego, w: Sprawozdania z czynności i posiedzeń PAU. Styczeń - grudzień 1950, Kraków, s. 503-509.

Stieber Z., 1957, Elementy prozodii w dialektach kaszubskich (iloczas, intonacja wyrazowa, przycisk wyrazowy), „Slavia” XXVI, s. 362-364.

Stokhof W.A.L., 1973, Notes on the Phonemic System of the Gtówczyce Dialect, w: A. van Holk (red.), Dutch Contributions to the Seventh International Congress of Slavists. Warsaw, August 21-27, 1973, The Hague - Paris, s. 133-152.

Stokhof W.A.L., 1973b, The Extinct East-Slovincian Kluki-Dialect. Phonology and Morphology, The Hague - Paris.

Ściebora A., 1973, Wymowa samogłosek nosowych w gwarach kaszubskich, Wrocław - Warszawa - Kraków - Gdańsk.

Topolińska Z., 1958, Aktualny stan akcentu kaszubskiego, „Slavia” XXVII, s. 381-395.

Topolińska Z., 1960, Zu Fragen des kaschubischen Vokalismus, „Zeitschrift für Slawistik" V/2, s. $161-170$.

Topolińska Z., 1967, Teksty gwarowe centralnokaszubskie z komentarzem fonologicznym, „Studia z Filologii Polskiej i Słowiańskiej” 7, s. 88-125.

Topolińska Z., 1969, Teksty gwarowe pótnocnokaszubskie z komentarzem fonologicznym, „Studia z Filologii Polskiej i Słowiańskiej” 8, s. 67-93. 
Topolińska Z., 1974, A historical phonology of the Kashubian dialects of Polish, The Hague - Paris. Topolińska Z., 1999, Z historii badań kaszubszczyzny. Gwara luzińska, „Acta Cassubiana” 1, s. $277-294$.

Urbańczyk S., 1984, Zarys dialektologii polskiej, Warszawa.

\title{
LECHOSŁAW JOCZ
}

\section{The Position of Luzino Dialect among Kashubian Dialects in Light of Phonetic and Phonological Facts}

\begin{abstract}
Summary
The article discusses the position of the Luzino dialect among Kashubian dialects in the light of phonetic and phonological features. The analysis takes into account eleven vowel features, one consonant feature and two prosodical features. A significant part of the discussed phenomena are the recent phenomena that have gone unnoticed, or been dealt with only marginally in the existing literature on the subject. One archaism links the Luzino dialect with the core central Kashubian area, but it is differentiated by seven innovations. The peripheral central Kashubian dialects indicate stronger relationships with the area of Luzino (one important archaism and one significant north Kashubian innovation). Three archaisms and nine innovations link the Luzino dialect with the north Kashubian area. Two vocal changes are typical only of the discussed area, and differentiate it from northern as well as southern Kashubian. From the phonetic and phonological point of view, the Luzino dialect should undoubtedly be classified as a marginal north Kashubian dialect.
\end{abstract}

Keywords: Kashubian language, Kashubian dialectology, Luzino dialect, phonetics, phonology 
